IZA DP No. 8500

Long Term Trends in Fair and Unfair Inequality in the United States

Andrew Hussey

Michael Jetter

September 2014 


\title{
Long Term Trends in Fair and Unfair Inequality in the United States
}

\author{
Andrew Hussey \\ University of Memphis \\ Michael Jetter \\ Universidad EAFIT \\ and IZA
}

\section{Discussion Paper No. 8500 \\ September 2014}

\author{
IZA \\ P.O. Box 7240 \\ 53072 Bonn \\ Germany \\ Phone: +49-228-3894-0 \\ Fax: +49-228-3894-180 \\ E-mail: iza@iza.org
}

Any opinions expressed here are those of the author(s) and not those of IZA. Research published in this series may include views on policy, but the institute itself takes no institutional policy positions. The IZA research network is committed to the IZA Guiding Principles of Research Integrity.

The Institute for the Study of Labor (IZA) in Bonn is a local and virtual international research center and a place of communication between science, politics and business. IZA is an independent nonprofit organization supported by Deutsche Post Foundation. The center is associated with the University of Bonn and offers a stimulating research environment through its international network, workshops and conferences, data service, project support, research visits and doctoral program. IZA engages in (i) original and internationally competitive research in all fields of labor economics, (ii) development of policy concepts, and (iii) dissemination of research results and concepts to the interested public.

IZA Discussion Papers often represent preliminary work and are circulated to encourage discussion. Citation of such a paper should account for its provisional character. A revised version may be available directly from the author. 


\section{ABSTRACT}

\section{Long Term Trends in Fair and Unfair Inequality in the United States}

This paper analyzes the microeconomic sources of wage inequality in the United States from 1967-2012. Decomposing inequality into factors categorized by degree of personal responsibility, we find that education is able to explain more than twice as much of inequality today as 45 years ago. However, neither hours worked nor education, industry, marital status, or geographical location is able to explain the observed general rise in inequality. In fact, "unfair" inequality has risen faster than "fair" inequality, regardless of the set of variables chosen as fair sources of inequality (resulting from responsibility factors). We also examine inequalities within gender and racial groups and across U.S. states. Several noteworthy findings emerge. Wage inequality among males used to be lower than among females until 1990, but today the opposite is true. We also find several occasions where the distinction between the raw Gini and the Gini adjusted for certain characteristics produces different conclusions. For instance, raw inequality among black females decreased since 1969, but if we acknowledge differences resulting from hours worked and educational outcomes as "fair" inequalities, the remaining inequality measure has increased. We also find that there is substantial geographic heterogeneity in trends of unfair and overall inequality.

\section{NON-TECHNICAL SUMMARY}

This paper decomposes inequality in the United States into factors related to responsibility (e.g., hours worked, education) and non-responsibility (e.g., gender, race), using yearly data since 1967. We find that the reasons for the rise in income inequality are partially located in the increasing returns to education. Not having a school degree gets punished much harsher on the labor market today than in the past. The reward for completing a college education, on the other hand, has increased substantially. We then analyze inequality within gender, race, and geographical reasons. The main takeaway of the paper suggests that the reasons of the rise in income inequality can differ substantially across all these factors. Thus, potential policies targeting rising income inequality cannot be general, but rather need to specifically target the specific roots of income inequality.

JEL Classification: D31, D63, J31

Keywords: income inequality, Gini coefficient, unfair inequality

Corresponding author:

Michael Jetter

Department of Economics

School of Economics and Finance

Universidad EAFIT

Carrera 497 Sur-50, Avenida Las Vegas

Medellín

Colombia

E-mail: mjetter7@gmail.com

\footnotetext{
* We thank the Universidad EAFIT for providing excellent research support in this project. We are also grateful to Susana Berrio Montoya and Alejandra Montoya Agudelo for outstanding research assistance. All remaining errors are our own.
} 


\section{Introduction}

As has been well documented, inequality worldwide and in the United States has steadily grown over the past years. In the United States, the Gini coefficient, the most prominent measure of income inequality, increased by 23 percent over the last 30 years (from 0.31 in 1980 to 0.38 in 2008). By this measure, there are only three countries in the OECD with higher inequality (Turkey, Mexico, and Israel). A political debate continues to be waged regarding the causes and consequences of this rising inequality, and arguments from both sides of the aisle have reached a fever pitch (see Mankiw, 2013, for a recent summary). But perhaps more so than in the past several decades, these arguments have gone beyond causes and consequences of income inequality and redistributive policies, with the intrinsic fairness or unfairness of inequality taking center stage. ${ }^{1}$ The Occupy Wall Street movement, the "47 percent," and the "One Percent" slogans are all political manifestations of increasingly divisive, normative views on inequality.

While extremist positions are often the most vocalized, it appears likely that most people's views regarding income inequality are more moderate and nuanced. Many would agree that some kind of inequality in outcomes is beneficial for a society, providing incentives to work and allocating resources efficiently, but at which point does a fair remuneration of contributions stop and unjust inequality begin? For example, Alesina and Angeletos (2005) summarize that "[i]f a society believes that individual effort determines income, and that all have a right to enjoy the fruits of their effort, it will choose low redistribution and low taxes." The factors underlying specific earnings differentials are of particular importance in determining the resulting attitudes towards the fairness or unfairness of those differentials (see Gaertner and Schwettmann, 2007; Cappelen et al., 2007). Thus, the source of the underlying income inequality matters in terms of which (if any) policies we might choose to change the income distribution, e.g., by setting tax structures. This reflects the idea that a distinction is often made between inequality of opportunities and inequality of outcomes, where the former more readily emphasizes individual responsibility in determining earnings, at least among factors that are within an individual's control. ${ }^{2}$

\footnotetext{
${ }^{1}$ See for example David et al. (2006) and Dynan and Ravina (2007) for potential utility consequences of inequality.

${ }^{2}$ Several recent papers consider the (in)equality of opportunity, such as Lefranc et al. (2009) or Aaberge et al. (2011). See Bourguignon et al. (2007) for a study of the inequality of opportunity in Brazil and Ramos and Van de
} 
The goal of this paper is to decompose the contributing factors to measures of overall income inequality in the U.S. and how these factors have changed over time. In particular, following the methodology of Almås et al. (2011), we break down a person's wage into "non-responsibility factors" (factors that are largely outside of an individual's realm of influence, such as race and gender) and "responsibility factors" (factors that are more within an individual's control, such as hours worked and education). In this context, we offer five versions of responsibility factors, including different sets of characteristics. Based on these classifications, we decompose a standard Gini coefficient to obtain adjusted Ginis, where inequalities stemming from responsibility factors are used to determine the reference point of a fair wage. This adjusted Gini then measures "unfair" inequality, i.e. inequality stemming from non-responsibility factors. Almås et al. (2011), in pioneering this approach, find that unfair inequality in Norway actually increased from 1986 to 2005, even though the raw Gini has decreased. In another application of this method, Figueiredo (2011) and Figueiredo and Junior (2011) analyze Brazilian data.

To our knowledge, however, no similar study has yet been carried out using data from the United States. Thus, one contribution of our paper is to do just that. Second, unlike Almås et al. (2011), who carry out their decomposition in only two separate years, our analysis covers a sizeable time period of 46 years. This time span is substantially larger than much of the literature investigating income inequality in the United States, and allows us to address both long-term trends in inequality, but also similar (or potentially diverging) trends in unfair inequality, as well as changes in the degree to which various factors contribute to fair versus unfair inequality. Finally, our study goes beyond measures of inequality at the national level by analyzing trends (and contributing factors) of fair and unfair inequality within gender, race, and geographic areas.

Several interesting findings emerge from our analysis. We find that comparison of alternative adjusted Ginis, each of which consider different factors for which individuals are held accountable, helps to explain some of the contributing factors of inequality. In general, education has become a strong determinant of wage disparities. The lack of education today is punished heavily in the labor market, much more so than 45 years ago. In turn, the financial reward from attaining a college degree has substantially increased in relative terms. Overall, however, none of framework to study the effects from both inequality of endowments and outcomes. 
the conventional wage determinants are able to explain the general trend towards higher inequality of incomes. In other words, hours worked, educational attainment, job industry, household characteristics, and state of residence are not able to account for the persistent rise in income inequality over the past four decades.

We also find interesting conclusions regarding wage inequality within gender and race. Most notably, while inequality among men's wages used to be substantially lower than inequality among women's wages, today we observe the opposite. The distinction between raw inequality and inequality adjusted by hours worked and educational outcomes offers particular insight in several parts of our analysis. For example, unconditional wage inequality among black women has decreased since the late 1960s. Once we hold people responsible for hours worked and education, however, this trend is reversed, suggesting that unfair inequality (at least resulting from the use of this set of responsibility factors) has increased for this group.

Finally, developments in inequality in the United States have differed across geographic regions. Especially the northeastern states experienced a strong rise in inequality levels, both unadjusted and adjusted. Some midwestern states, on the other hand, are actually characterized by lower inequality today than 35 years ago. In this context, we again find differences in terms of what is defined as part of one's own responsibility set of variables.

The paper proceeds with a brief description of our data and methodology in sections 2 and 3 , before presenting our main empirical findings in sections 4 and 5. Finally, section 6 concludes with a brief discussion.

\section{Data}

Our analysis utilizes repeated cross-sectional data derived from the March Supplements of the Current Population Surveys (CPS). A strength of this data source is that it allows us to carry out the analysis for a large number of years, for the purpose of investigating possible changes in inequality and its sources over time. While some variables in the surveys have changed marginally over the years, the common data source allows for remarkable consistency and therefore comparability over time. We elect to use the years 1967 through 2012 in order to include a large span of time that has seen significant changes in demographics, education, and income levels in 
the United States. On the other hand, our desire to include a relatively rich set of variables to adjust for potential responsibility factors limits our dataset to this 46 year period, as several important variables (most notably a time consistent measure of industry of employment) began to be collected in the 1968 survey.

Our outcome variable is the individual's total pre-tax wage and salary income for the calendar year. ${ }^{3}$ We restrict the sample to those individuals aged 16 and over who were employed and reported non-zero earnings for the year. Using this sample, we first check whether our derived raw Gini is representative of other published Gini coefficients, in particular the one calculated by the U.S. Census Bureau. We follow the Census methodology for calculating Ginis in that we derive 3-year rolling averages, and we extend this methodology to all our adjusted Ginis presented throughout the paper. While our sample of working individuals exhibits consistently lower inequality than the overall census sample, the correlation between our raw (unadjusted) Gini derived from the CPS returns a coefficient of 0.974 with the Census Gini. Reasons for the consistent gap between the Census Gini and our Gini include their methodology of measuring household income, whereas we are using individual income, and our limiting the sample to those with nonzero earned income, following Almås et al. (2011). We elected to use individual earnings, rather than household income or size-adjusted household income, out of a desire to adjust for various sets of individual-level responsibility factors. The graphical representation in Figure 1 also shows that for both measurements raw inequality has constantly increased over the past 45 years with a particular jump in the mid-1990s. ${ }^{4}$

An important consideration when using income variables in the CPS is dealing with topcoded income values. To protect respondent confidentiality, the U.S. Census Bureau censors the incomes of individuals earning above specific levels. These levels have changed over time in nonsystematic ways and affect a varying, often non-trivial, percentage of the sample. The method (if any) used to adjust for this censoring has important implications for statistics relating to the earnings distribution (Larrimore et al., 2008; Burkhauser et al., 2011). For the years 1976

\footnotetext{
${ }^{3}$ While tax policies and other transfers have changed substantially over the last several decades, and naturally affect after-tax income inequality, our analysis is unfortunately limited to pre-tax income due to the impossibility of determining the tax filing status among married individuals. For a discussion regarding the choice between alternative income variables, see Armour et al. (2013).

${ }^{4}$ In 1994, major changes were made in the way that the March CPS was collected, and changes were also made in internal censoring points (see Burkhauser et al., 2009).
} 


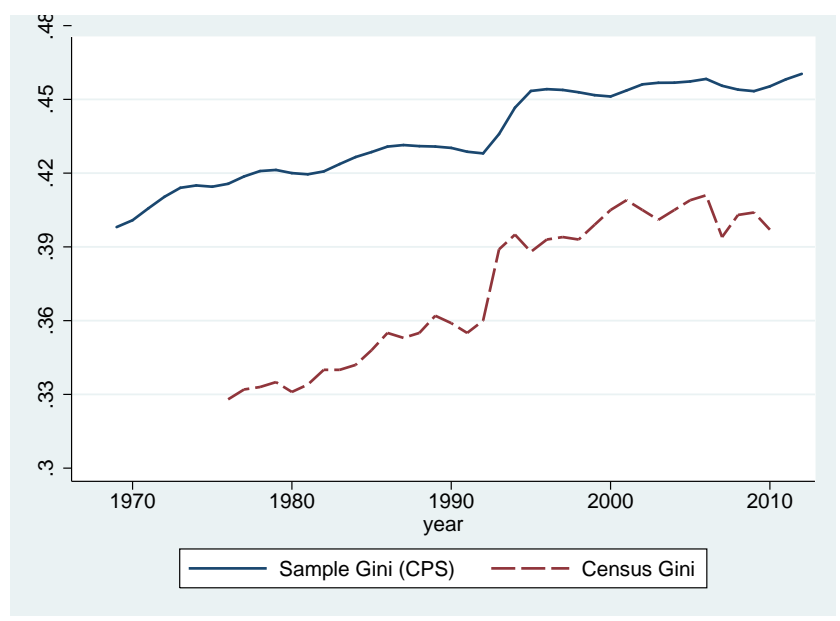

Figure 1: The Gini derived from the CPS sample versus the Census Gini

through 2000, we use the mean earnings among various demographic groups who were topcoded, as provided by Larrimore et al. (2008), who also show that, by using this series, resulting Gini coefficients very closely match those derived from internal Census data including actual incomes. In subsequent years, the U.S. Census Bureau provides similar cell means for topcoded groups of individuals. Finally, for the years prior to 1976 we multiplied topcoded wages by 1.5, an approximation for mean earnings that has often been made in the labor economics literature (Katz and Murphy, 1992; Lemieux, 2006a). The number of topcoded individuals in our sample is particularly low for these years - no more than 0.1 percent. We found the results to be quite insensitive to alternative multiplication factors for topcoded earnings in these years.

In terms of the variables explaining one's wage, we follow and extend Almås et al. (2011). Thus, we start with variables that are presumably most likely within an individual's responsibility or control, like hours worked or educational attainment, and then gradually move towards factors for which one is less responsible (e.g., geographical location) or not responsible at all (e.g., race or gender). Of course, one can end up in philosophical discussions regarding to what degree some characteristics - education, for example - are within a person's control, and therefore whether they contribute to fair or unfair inequality. Our intention is not to enter this debate. Rather, we offer several different definitions of what lies within the realm of responsibility of the average citizen, so the reader can pick her preferred definition.

Specifically, we start by including solely hours worked (linear and squared term) in one's 
responsibility set, thus any wage inequalities resulting from the quantity of time dedicated to work do not contribute towards this specific adjusted Gini (AG 1: $\{\mathrm{H}\})$. We then sequentially add education (AG 2: $\{\mathrm{H}, \mathrm{EDU}\})$, industry (AG 3: $\{\mathrm{H}, \mathrm{EDU}, \mathrm{IND}\})$, household variables, namely marital status and number of children (AG 4: $\{\mathrm{H}, \mathrm{EDU}, \mathrm{IND}, \mathrm{HH}\})$, and geographical location (AG 5: \{H, EDU, IND, HH, STATE $\}$ ) to the set of responsibility factors. Note that every adjusted Gini also includes the previously added variables into the responsibility set, similar to Almås et al. (2011).

For education variables, we distinguish between four categories representing the highest education the individual completed: no high school degree, some college education, and college degree, with a high school graduate forming the omitted category. In terms of industry, we incorporate 17 categorical variables that reflect broad classifications of industries, using the 1950 Census Bureau industrial classification system in order to maintain comparability over time. ${ }^{5}$ Regarding basic household characteristics, our data set allows us to include dummy variables for married, widowed, separated, divorced (with single forming the reference category), and the number of children. Further, we include binary indicators for all U.S. states and also whether the respondent lives in a metropolitan area. All estimations also incorporate age, age squared, categorical variables for race/ethnicity (black, Hispanic, other, and white forming the omitted group), gender, and an indicator variable for veteran status. ${ }^{6}$ However, we do not derive an adjusted Gini that incorporates these demographic characteristics into the responsibility set.

Sample means and standard deviations of the majority of our included variables are found in Table 1, where we pick five representative 3-year periods in different decades throughout our sample. Average real incomes, adjusted by inflation in using the Consumer Price Index

\footnotetext{
${ }^{5}$ We collapse the industry categories provided by the CPS to the following broader groups: (1) Agriculture, Forestry, and Fishing; (2) Mining; (3) Construction; (4) Manufacturing - Durable Goods; (5) Manufacturing Nondurable; (6) Transportation; (7) Telecommunications; (8) Utilities and Sanitary Services; (9) Wholesale Trade; (10) Retail Trade; (11) Finance, Insurance, and Real Estate; (12) Business and Repair Services; (13) Personal Services Goods; (14) Entertainment and Recreation Services; (15) Professional and Related Services; (16) Public Administration; (17) Other.

${ }^{6}$ The number of racial categories in the CPS has increased over time. Prior to 1987, categories were limited to black, white, and other. In 1988, American Indian and Asian categories were introduced. Respondents could report more than one race beginning in 2003, drastically increasing the number of potential categories. Similarly, information on Hispanic origin was not collected prior to 1971. In a balance between maintaining comparability over time and capturing the important rise in the Hispanic demographic over time, we collapse race and ethnic categories into four: black, white (non-Hispanic), Hispanic (non-black), and other. Removing the Hispanic variable from our analysis in 1971 and years shortly after had no effect on our estimated Gini coefficients (adjusted or otherwise), suggesting the lack of data on Hispanic origin prior to 1971 is not a serious concern.
} 
from 2013 as a reference point, have risen substantially over the sample period. Dispersion (standard deviations) in these incomes has increased even more - a statistic that already gives us a glimpse at increasing raw inequality over time. The average number of hours worked has remained remarkably stable over time, fluctuating around 38.6 and 39.5. In terms of all educational categories, we notice a strong shift towards academic attainment. The fraction of employed respondents without a high school degree decreased from about 37 percent in 1967 1969 to nine percent in 2010 - 2012, whereas the percentage of college graduates increased from 13 to 35 percent in that timeframe.

In terms of marital status, the single lifestyle has become more popular over time - a trend reflected by the fraction of married individuals (decreasing from 72 to 59 percent), the fraction of divorced respondents (up from 3.7 to 10.4 percent), and the omitted category of never married singles (up from 18.5 to 26.3 percent). Somewhat in line with this trend is the average number of children, which decreased steadily from almost 1.3 to 0.97 per person. Further, our sample of employed individuals has become more female, slightly older, and more racially heterogeneous throughout the sample period. Finally, the percentage of military veterans in the samples has dramatically decreased over time.

\section{Methodology}

Following the methodology developed by Almås et al. (2011), we start with the raw Gini index and then add explanatory factors, ordered by their degree of responsibility. Of course, precisely defining for which factors a person should be held responsible is impossible and quite subjective. We offer several versions, out of which the reader can choose her preferred definition of responsibility and non-responsibility factors. Comparison across specifications also allows us to gain a better understanding regarding the relative importance of each factor in explaining income inequality.

We first estimate a basic earnings equation for individual $i$ 's wage $(y)$ in year $t$, grouping together responsibility factors $\left(\boldsymbol{x}_{i t}^{R}\right)$ and non-responsibility factors $\left(\boldsymbol{x}_{i t}^{N R}\right)$ :

$$
\log \left(y_{i t}\right)=\beta \boldsymbol{x}_{i t}^{R}+\gamma \boldsymbol{x}_{i t}^{N R}+\epsilon_{i t},
$$


Table 1: Descriptive statistics

\begin{tabular}{|c|c|c|c|c|c|}
\hline & \multicolumn{5}{|c|}{ Years } \\
\hline & 1967-1969 & 1977-1979 & 1987-1989 & 1997-1999 & 2010-2012 \\
\hline Real wage income & $\begin{array}{c}30,686 \\
(24,971)\end{array}$ & $\begin{array}{c}32,727 \\
(27,334)\end{array}$ & $\begin{array}{c}35,986 \\
(32,783)\end{array}$ & $\begin{array}{c}41,958 \\
(47,294)\end{array}$ & $\begin{array}{c}48,216 \\
(60,509)\end{array}$ \\
\hline Hours worked & $\begin{array}{c}39.308 \\
(13.307)\end{array}$ & $\begin{array}{c}38.665 \\
(13.171)\end{array}$ & $\begin{array}{c}39.328 \\
(13.203)\end{array}$ & $\begin{array}{c}39.502 \\
(13.354)\end{array}$ & $\begin{array}{c}38.645 \\
(12.852)\end{array}$ \\
\hline No high school & $\begin{array}{c}0.369 \\
(0.483)\end{array}$ & $\begin{array}{c}0.234 \\
(0.423)\end{array}$ & $\begin{array}{c}0.158 \\
(0.365)\end{array}$ & $\begin{array}{l}0.133 \\
(0.34)\end{array}$ & $\begin{array}{c}0.091 \\
(0.288)\end{array}$ \\
\hline Some college & $\begin{array}{c}0.125 \\
(0.331)\end{array}$ & $\begin{array}{c}0.181 \\
(0.385)\end{array}$ & $\begin{array}{c}0.208 \\
(0.406)\end{array}$ & $\begin{array}{c}0.284 \\
(0.451)\end{array}$ & $\begin{array}{c}0.294 \\
(0.456)\end{array}$ \\
\hline College & $\begin{array}{c}0.127 \\
(0.333)\end{array}$ & $\begin{array}{c}0.184 \\
(0.388)\end{array}$ & $\begin{array}{c}0.237 \\
(0.425)\end{array}$ & $\begin{array}{c}0.267 \\
(0.443)\end{array}$ & $\begin{array}{c}0.348 \\
(0.476)\end{array}$ \\
\hline Married & $\begin{array}{c}0.717 \\
(0.451)\end{array}$ & $\begin{array}{c}0.644 \\
(0.479)\end{array}$ & $\begin{array}{c}0.61 \\
(0.488)\end{array}$ & $\begin{array}{c}0.593 \\
(0.491)\end{array}$ & $\begin{array}{c}0.594 \\
(0.491)\end{array}$ \\
\hline Widowed & $\begin{array}{c}0.04 \\
(0.195)\end{array}$ & $\begin{array}{c}0.028 \\
(0.164)\end{array}$ & $\begin{array}{c}0.023 \\
(0.149)\end{array}$ & $\begin{array}{c}0.018 \\
(0.134)\end{array}$ & $\begin{array}{l}0.017 \\
(0.13)\end{array}$ \\
\hline Separated & $\begin{array}{c}0.021 \\
(0.142)\end{array}$ & $\begin{array}{c}0.023 \\
(0.149)\end{array}$ & $\begin{array}{c}0.023 \\
(0.151)\end{array}$ & $\begin{array}{c}0.023 \\
(0.151)\end{array}$ & $\begin{array}{c}0.022 \\
(0.146)\end{array}$ \\
\hline Divorced & $\begin{array}{l}0.037 \\
(0.19)\end{array}$ & $\begin{array}{c}0.068 \\
(0.251)\end{array}$ & $\begin{array}{c}0.09 \\
(0.286)\end{array}$ & $\begin{array}{c}0.106 \\
(0.308)\end{array}$ & $\begin{array}{c}0.104 \\
(0.305)\end{array}$ \\
\hline \# of children & $\begin{array}{c}1.277 \\
(1.581)\end{array}$ & $\begin{array}{c}1.018 \\
(1.315)\end{array}$ & $\begin{array}{c}0.918 \\
(1.156)\end{array}$ & $\begin{array}{c}0.906 \\
(1.153)\end{array}$ & $\begin{array}{c}0.973 \\
(1.170)\end{array}$ \\
\hline Metro area & $\begin{array}{c}0.677 \\
(0.468)\end{array}$ & $\begin{array}{c}0.594 \\
(0.491)\end{array}$ & $\begin{array}{c}0.755 \\
(0.430)\end{array}$ & $\begin{array}{c}0.789 \\
(0.408)\end{array}$ & $\begin{array}{c}0.810 \\
(0.392)\end{array}$ \\
\hline Metro area unknown & $\begin{array}{c}0 \\
(0)\end{array}$ & $\begin{array}{c}0.141 \\
(0.348)\end{array}$ & $\begin{array}{c}0.017 \\
(0.129)\end{array}$ & $\begin{array}{c}0.003 \\
(0.053)\end{array}$ & $\begin{array}{c}0.008 \\
(0.091)\end{array}$ \\
\hline Female & $\begin{array}{c}0.378 \\
(0.485)\end{array}$ & $\begin{array}{c}0.429 \\
(0.495)\end{array}$ & $\begin{array}{c}0.465 \\
(0.499)\end{array}$ & $\begin{array}{c}0.475 \\
(0.499)\end{array}$ & $\begin{array}{c}0.484 \\
(0.5)\end{array}$ \\
\hline Veteran & $\begin{array}{c}0.299 \\
(0.458)\end{array}$ & $\begin{array}{l}0.228 \\
(0.42)\end{array}$ & $\begin{array}{c}0.15 \\
(0.357)\end{array}$ & $\begin{array}{c}0.104 \\
(0.305)\end{array}$ & $\begin{array}{c}0.065 \\
(0.247)\end{array}$ \\
\hline Age & $\begin{array}{c}39.258 \\
(14.067)\end{array}$ & $\begin{array}{c}36.858 \\
(13.763)\end{array}$ & $\begin{array}{c}37.519 \\
(12.783)\end{array}$ & $\begin{array}{c}39.213 \\
(12.647)\end{array}$ & $\begin{array}{c}41.738 \\
(13.267)\end{array}$ \\
\hline White & $\begin{array}{l}0.892 \\
(0.31)\end{array}$ & $\begin{array}{c}0.795 \\
(0.404)\end{array}$ & $\begin{array}{c}0.78 \\
(0.414)\end{array}$ & $\begin{array}{c}0.714 \\
(0.452)\end{array}$ & $\begin{array}{c}0.649 \\
(0.477)\end{array}$ \\
\hline Black & $\begin{array}{c}0.099 \\
(0.299)\end{array}$ & $\begin{array}{c}0.082 \\
(0.274)\end{array}$ & $\begin{array}{c}0.085 \\
(0.278)\end{array}$ & $\begin{array}{c}0.089 \\
(0.285)\end{array}$ & $\begin{array}{c}0.105 \\
(0.306)\end{array}$ \\
\hline Hispanic & $\begin{array}{c}0 \\
(0)\end{array}$ & $\begin{array}{c}0.1 \\
(0.3)\end{array}$ & $\begin{array}{c}0.103 \\
(0.303)\end{array}$ & $\begin{array}{c}0.154 \\
(0.361)\end{array}$ & $\begin{array}{c}0.159 \\
(0.365)\end{array}$ \\
\hline Other & $\begin{array}{c}0.009 \\
(0.092)\end{array}$ & $\begin{array}{c}0.023 \\
(0.151)\end{array}$ & $\begin{array}{c}0.032 \\
(0.177)\end{array}$ & $\begin{array}{c}0.043 \\
(0.204)\end{array}$ & $\begin{array}{c}0.088 \\
(0.283)\end{array}$ \\
\hline $\mathrm{N}$ & 146,125 & 181,342 & 184,681 & 168,166 & 242,282 \\
\hline
\end{tabular}

Note: Reported are sample means and standard deviations in parentheses of employed individuals with non-missing and non-zero wages in the

Current Population Surveys from 1967 - 2012, grouped in 3-year periods. 
where $\epsilon_{i t}$ represents the usual error term. This equation corresponds exactly to equation 6 in Almås et al. (2011). We start by including all of our variables into $\boldsymbol{x}_{i t}^{N R}$, which is the equivalent of the generic Gini estimation. We then shift hours worked to be included in $\boldsymbol{x}_{i t}^{R}$, followed by an estimation adding educational attainment variables, and so on. The estimated "fair" income $z_{i t}^{G P P}$ can then be expressed, as shown in Almås et al. (2011), by

$$
z_{i t}^{G P P}=\frac{\exp \left(\beta \boldsymbol{x}_{i t}^{R}\right)}{\sum_{j} \exp \left(\beta \boldsymbol{x}_{j t}^{R}\right)} \sum_{j} y_{j t},
$$

where the superscript GPP stands for the generalized proportionality principle and $i \neq j$. The GPP holds that "an individual's claim is given by what would have been the average income in a hypothetical situation where everyone had the same responsibility vector as this individual" (Almås et al., 2011). The adjusted Gini, which takes into account any variables included in $\boldsymbol{x}_{i t}^{R}$ as responsibility factors, is calculated in the same way as the usual Gini coefficient - via construction of the Lorenz curve - but, rather than using realized income relative to the average income, it uses the difference between the realized income $y_{i t}$ and the "fair" income $z_{i t}^{G P P}$.7 Thus, the remaining adjusted Gini is said to be "unfair," as any remaining wage inequality is based on non-responsibility factors. We calculate the Gini coefficient and the sets of adjusted Ginis separately for each year of our sample and then produce the mentioned 3-year rolling averages.

Unfortunately, we cannot control for all factors determining a person's wage that have been found in the literature, both within the sphere of responsibility factors, as well as nonresponsibility factors. For example, variables describing work experience, the field of study, or some quality measurement of the attended academic institution have been found to be related to wages (e.g., see Grove et al., 2011), but are absent in the CPS data set. However, some existent variables may be closely related to these characteristics and could therefore mitigate these potential problems from omitted variables, such as age being a proxy for work experience or the job industry capturing the field of study, at least partially. In addition, the CPS sample does not provide information on preferences (e.g., work versus family) or noncognitive skills. Our goal is to use as much information as possible, given the data set at hand.

\footnotetext{
${ }^{7}$ Almås et al. (2012) provide details on the respective code in Stata.
} 


\section{Empirical Findings from Generic Wage Regressions}

To get a better understanding of wage determinants and their development over time, we begin by estimating traditional log wage regressions. Even though we do not expect these results to directly explain developments in inequality over time, unlike Gini coefficients, which are single distributional statistics, they provide some intuition as to which variables are important in explaining wages and whether these relationships are changing over time. Table 2 displays the results of several regressions, using the same 5 representative 3 -year periods that were used in Table 1.

In order to guarantee comparability within regressions, we use the CPI deflator (using the year 2013 as a reference point) to adjust nominal wages to real wages. We sort the explanatory variables in an order similar to Almås et al. (2011), beginning our inequality analysis by including hours worked as a responsibility factor. We then gradually move towards variables that are (presumably) less subject to one's own responsibility: educational outcomes, industry (not displayed due to the large number of coefficients), civil status and number of children, the state one lives in (not displayed for the same reason), and finally demographic characteristics, such as gender and race. We also include the year of the observation as a regressor in order to control for potential influences from business cycles or other common time-specific factors.

First, Table 2 reveals that the importance of hours worked in determining one's wage has been decreasing since the late 1990s, although taking into account its squared term we see that the relationship has also become slightly more linear. Note also that among the individuals in our sample, the average worker has worked marginally fewer hours over time, likely due to an increase in part-time employees.

A large change, however, occurs for educational outcomes: at the end of the 1960s, not obtaining a high school degree was punished by a wage decrease of about 24.5 percent on average, whereas today the opportunity cost of not finishing high school lowers the mean wage by 30 percent, relative to achieving a high school degree (the omitted category). This development is complemented by the rising reward for entering higher education, as receiving some college education used to raise one's wage by ten percent on average, but today produces an average reward of over 14 percent. Yet the starkest jump is observed for college graduates. At the end of the 1960s an average college graduate was able to earn 37 percent more than a high 
Table 2: OLS Results. Dependent variable is the logarithm of real wage earnings.

\begin{tabular}{|c|c|c|c|c|c|}
\hline & $\begin{array}{c}(1) \\
1967-1969\end{array}$ & $\begin{array}{c}(2) \\
\mathbf{1 9 7 7 - 1 9 7 9}\end{array}$ & $\begin{array}{c}\text { Years } \\
(3) \\
\text { 1987-1989 }\end{array}$ & $\begin{array}{c}(4) \\
1997-1999\end{array}$ & $\begin{array}{c}(5) \\
\mathbf{2 0 1 0 - 2 0 1 2}\end{array}$ \\
\hline Hours worked & $\begin{array}{c}0.0648^{* * *} \\
(0.0007)\end{array}$ & $\begin{array}{c}0.0641^{* * *} \\
(0.0007)\end{array}$ & $\begin{array}{c}0.0673^{* * *} \\
(0.0006)\end{array}$ & $\begin{array}{c}0.0554^{* * *} \\
(0.0007)\end{array}$ & $\begin{array}{c}0.0560^{* * *} \\
(0.0006)\end{array}$ \\
\hline Hours worked swuared & $\begin{array}{c}-0.0005^{* * *} \\
(0.0000)\end{array}$ & $\begin{array}{c}-0.0005^{* * *} \\
(0.0000)\end{array}$ & $\begin{array}{c}-0.0005^{* * *} \\
(0.0000)\end{array}$ & $\begin{array}{c}-0.0004^{* * *} \\
(0.000)\end{array}$ & $\begin{array}{c}-0.0004^{* * *} \\
(0.000)\end{array}$ \\
\hline No high school & $\begin{array}{c}-0.245^{* * *} \\
(0.005)\end{array}$ & $\begin{array}{c}-0.286^{* * *} \\
(0.006)\end{array}$ & $\begin{array}{c}-0.291^{* * *} \\
(0.006)\end{array}$ & $\begin{array}{c}-0.303^{* * *} \\
(0.007)\end{array}$ & $\begin{array}{c}-0.299^{* * *} \\
(0.007)\end{array}$ \\
\hline Some college & $\begin{array}{c}0.103^{* * *} \\
(0.006)\end{array}$ & $\begin{array}{c}0.100^{* * *} \\
(0.005)\end{array}$ & $\begin{array}{c}0.139^{* * *} \\
(0.005)\end{array}$ & $\begin{array}{c}0.148^{* * *} \\
(0.005)\end{array}$ & $\begin{array}{c}0.143^{* * *} \\
(0.004)\end{array}$ \\
\hline College & $\begin{array}{c}0.372^{* * *} \\
(0.006)\end{array}$ & $\begin{array}{c}0.318^{* * *} \\
(0.006)\end{array}$ & $\begin{array}{c}0.409^{* * *} \\
(0.005)\end{array}$ & $\begin{array}{c}0.499^{* * *} \\
(0.005)\end{array}$ & $\begin{array}{c}0.533^{* * *} \\
(0.004)\end{array}$ \\
\hline Married & $\begin{array}{c}0.269^{* * *} \\
(0.007)\end{array}$ & $\begin{array}{c}0.211^{* * *} \\
(0.006)\end{array}$ & $\begin{array}{c}0.185^{* * *} \\
(0.006)\end{array}$ & $\begin{array}{c}0.165^{* * *} \\
(0.006)\end{array}$ & $\begin{array}{c}0.166^{* * *} \\
(0.005)\end{array}$ \\
\hline Widowed & $\begin{array}{c}0.214^{* * *} \\
(0.012)\end{array}$ & $\begin{array}{c}0.192^{* * *} \\
(0.014)\end{array}$ & $\begin{array}{c}0.128^{* * *} \\
(0.014)\end{array}$ & $\begin{array}{c}0.120^{* * *} \\
(0.017)\end{array}$ & $\begin{array}{c}0.084^{* * *} \\
(0.014)\end{array}$ \\
\hline Separated & $\begin{array}{c}0.146^{* * *} \\
(0.015)\end{array}$ & $\begin{array}{c}0.136^{* * *} \\
(0.014)\end{array}$ & $\begin{array}{c}0.072^{* * *} \\
(0.013)\end{array}$ & $\begin{array}{c}0.033^{* *} \\
(0.013)\end{array}$ & $\begin{array}{c}0.036^{* * *} \\
(0.011)\end{array}$ \\
\hline Divorced & $\begin{array}{c}0.244^{* * *} \\
(0.012)\end{array}$ & $\begin{array}{c}0.201^{* * *} \\
(0.009)\end{array}$ & $\begin{array}{c}0.132^{* * *} \\
(0.008)\end{array}$ & $\begin{array}{c}0.100^{* * *} \\
(0.008)\end{array}$ & $\begin{array}{c}0.098^{* * *} \\
(0.006)\end{array}$ \\
\hline \# of children & $\begin{array}{c}-0.012^{* * *} \\
(0.001)\end{array}$ & $\begin{array}{c}-0.025^{* * *} \\
(0.002)\end{array}$ & $\begin{array}{c}-0.022^{* * *} \\
(0.002)\end{array}$ & $\begin{array}{c}-0.008^{* * *} \\
(0.002)\end{array}$ & $\begin{array}{c}0.012^{* * *} \\
(0.002)\end{array}$ \\
\hline Female & $\begin{array}{c}-0.512^{* * *} \\
(0.006)\end{array}$ & $\begin{array}{c}-0.486^{* * *} \\
(0.005)\end{array}$ & $\begin{array}{c}-0.341^{* * *} \\
(0.004)\end{array}$ & $\begin{array}{c}-0.315^{* * *} \\
(0.004)\end{array}$ & $\begin{array}{c}-0.255^{* * *} \\
(0.004)\end{array}$ \\
\hline Veteran & $\begin{array}{c}0.061^{* * *} \\
(0.005)\end{array}$ & $\begin{array}{c}0.072^{* * *} \\
(0.005)\end{array}$ & $\begin{array}{c}0.035^{* * *} \\
(0.005)\end{array}$ & $\begin{array}{l}0.006 \\
(0.007)\end{array}$ & $\begin{array}{c}0.015^{* *} \\
(0.007)\end{array}$ \\
\hline Age & $\begin{array}{c}0.083^{* * *} \\
(0.001)\end{array}$ & $\begin{array}{c}0.088^{* * *} \\
(0.001)\end{array}$ & $\begin{array}{c}0.082^{* * *} \\
(0.001)\end{array}$ & $\begin{array}{c}0.082^{* * *} \\
(0.001)\end{array}$ & $\begin{array}{c}0.074^{* * *} \\
(0.001)\end{array}$ \\
\hline Age squared & $\begin{array}{c}-0.001^{* * *} \\
(0.000)\end{array}$ & $\begin{array}{c}-0.001^{* * *} \\
(0.000)\end{array}$ & $\begin{array}{c}-0.001^{* * *} \\
(0.000)\end{array}$ & $\begin{array}{c}-0.001^{* * *} \\
(0.000)\end{array}$ & $\begin{array}{c}-0.001^{* * *} \\
(0.000)\end{array}$ \\
\hline Black & $\begin{array}{c}-0.182^{* * *} \\
(0.007)\end{array}$ & $\begin{array}{c}-0.095^{* * *} \\
(0.007)\end{array}$ & $\begin{array}{c}-0.115^{* * *} \\
(0.007)\end{array}$ & $\begin{array}{c}-0.122^{* * *} \\
(0.007)\end{array}$ & $\begin{array}{c}-0.137^{* * *} \\
(0.006)\end{array}$ \\
\hline Other & $\begin{array}{c}-0.080^{* * *} \\
(0.023)\end{array}$ & $\begin{array}{c}-0.119^{* * *} \\
(0.015)\end{array}$ & $\begin{array}{c}-0.109^{* * *} \\
(0.012)\end{array}$ & $\begin{array}{c}-0.100^{* * *} \\
(0.010)\end{array}$ & $\begin{array}{c}-0.072^{* * *} \\
(0.006)\end{array}$ \\
\hline Year & $\begin{array}{c}0.042^{* * *} \\
(0.002)\end{array}$ & $\begin{array}{c}0.010^{* * *} \\
(0.002)\end{array}$ & $\begin{array}{l}0.004^{*} \\
(0.002)\end{array}$ & $\begin{array}{c}0.032^{* * *} \\
(0.002)\end{array}$ & $\begin{array}{c}-0.004^{*} \\
(0.002)\end{array}$ \\
\hline $\begin{array}{l}N \\
R^{2}\end{array}$ & $\begin{array}{c}146,125 \\
0.561\end{array}$ & $\begin{array}{c}181,342 \\
0.477\end{array}$ & $\begin{array}{c}184,681 \\
0.498\end{array}$ & $\begin{array}{c}168,166 \\
0.459\end{array}$ & $\begin{array}{c}242,282 \\
0.462\end{array}$ \\
\hline
\end{tabular}

Notes: Standard errors in parentheses. ${ }^{*} p<0.10,{ }^{* *} p<0.05,{ }^{* * *} p<0.01$.

All regressions include industry- (17) and states-fixed effects, but also binary variables for living in a metropolitan area or whether the exact living area is unknown. 
school graduate, but today this difference has increased to over 53 percent. Notice that we first observe a downward trend for college graduates' wages at the end of the 1970s, but then college education increases its payoff strongly in the 1980s and thereafter. This significant increase in the returns to education in that time period is consistent with prior research, which has often attributed such a rise predominantly to skill-biased technical change, as well as fluctuations in the supply of educated workers (Bound and Johnson, 1992; Katz and Murphy, 1992).

Moving to family characteristics, a person's civil status used to explain a larger part of one's wage, yet we observe a strong trend in favor of single households, the omitted variable. For example, being married translated to an almost 27 percent wage increase 45 years ago, but today this "premium" is shrinking to under 17 percent. Further, it appears that employers may be becoming more welcoming to workers with children. 45 years ago, every child was associated with a 1.2 percent decrease in one's wage, whereas in more recent years this child penalty has turned into a premium that is equal in magnitude. Of course, some caution should be taken in interpreting these estimates as causal. Changes in coefficient estimates across years will not only be influenced by changes in returns to worker characteristics, but also changes in the composition of the workforce. Most notably, the large increase in women's labor force participation will affect the coefficients on family-related variables. Even among employed individuals, omitted variable bias is likely present in these estimations, as people with particular unobserved characteristics related to earnings likely have different educational attainment, civil status, etc.

Finally, Table 2 also displays the coefficients returned for other demographic characteristics, specifically gender, veteran status, age, and race. Notice that females earned over 50 percent less than males on average at the end of the 1960s, holding every other observable characteristic constant. This gender gap has been cut in half since then. Once again, however, we need to be careful to establish causality, as previous research has shown that personal preferences, ethics, and noncognitive skills can influence one's wage and these variables tend to be differently distributed across gender (see Grove et al., 2011). In terms of racial differences, African Americans earned over 18 percent less than whites (the omitted category) 45 years ago. This difference has declined remarkably until the end of the 1970s by almost one half, but discouragingly has since increased again.

Overall, estimates from our wage regressions confirm conventional findings in the associated 
literature, and highlight developments in the labor market in the United States that may have contributed to increasing income inequality over the past 45 years. With this in mind, we now turn to the analysis of unfair inequality, distinguishing between responsibility and nonresponsibility factors.

\section{$5 \quad$ Fair and Unfair Inequality}

Figure 2 and Table 3 display some basic representations of the raw Gini coefficient derived from our sample and several versions of the adjusted Gini, where inequalities resulting from certain variables (responsibility factors) are used to estimate the benchmark case of perfect equality. For instance, when we include hours worked as a responsibility factor (AG 1: $\{\mathrm{H}\}$ ), wage inequalities resulting from hours worked are used to determine the benchmark case for a Gini equal to zero. On the other hand, any remaining differences in wages, which cannot be traced back to hours worked, would be considered as inequality and therefore form part of the adjusted Gini. Thus, the adjusted Gini represents the wage inequality derived from the non-responsibility factors. Keep in mind that all estimates represent 3-year rolling averages in order to filter out potential business cycles and provide smoother trends in our estimated Gini coefficients. For example, any variable displayed for the year 1970 represents the average of that derived value for 1968, 1969, and 1970. Table 3 displays five representative 3 -year time periods throughout our sample with a specific focus around the jumps occurring in the early 1990s.

Figure 2 gives us some indication of the sources of inequality and how they have changed over time. First, the raw Gini (left graph, top line) has constantly risen, from 0.40 in 1969 up to 0.46 in 2012. Once we include hours worked as a responsibility factor (AG 1: $\{\mathrm{H}\}$ ), the adjusted Gini in 2012 decreases to 0.42. Thus, about nine percent of today's inequality, as represented by a Gini coefficient, can be traced back to differences in hours worked. In 1969, this fraction was slightly higher (12.5 percent), as hours worked explained (relatively) more of income inequality.

As a next step, we add educational attainment to the set of responsibility factors (AG 2: $\{\mathrm{H}, \mathrm{EDU}\})$, further decreasing the adjusted Gini to 0.40. After that, holding people responsible for the industry they work in (AG 3: $\{\mathrm{H}, \mathrm{EDU}$. IND $\}$ ), their household characteristics (marital 
The raw Gini versus the adjusted Ginis

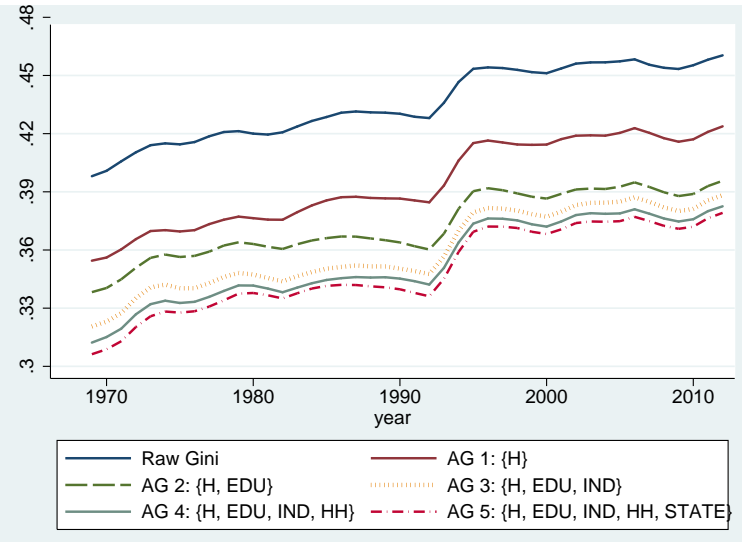

Contribution of variable groups

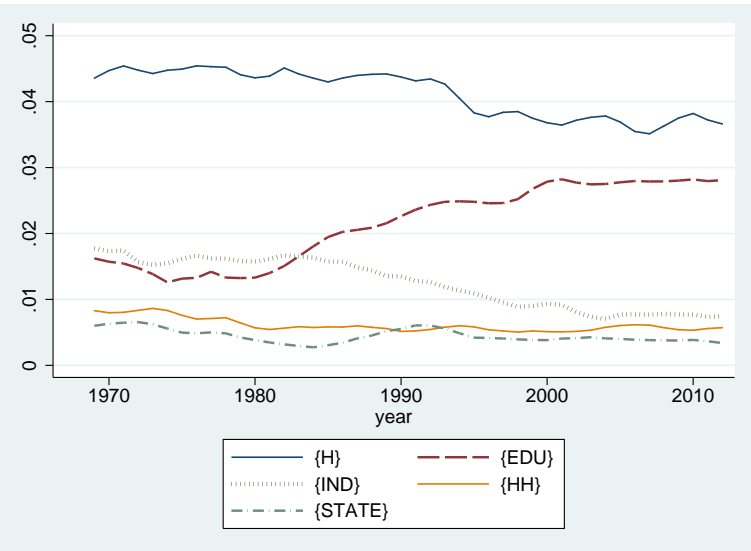

Figure 2: The raw and the adjusted Ginis, where $\{\mathrm{H}\}$ : hours worked; $\{$ EDU $\}$ : educational attainment; $\{$ IND $\}$ : industry fixed effects; $\{\mathrm{HH}\}$ : household characteristics; $\{\mathrm{STATE}\}$ : state fixed effects and metropolitan area.

Table 3: Adjusted Gini for different responsibility sets.

\begin{tabular}{|c|c|c|c|c|c|}
\hline Responsibility set & $1967-1969$ & 1990-1992 & 1993-1995 & 2004-2006 & 2010-2012 \\
\hline Raw Gini & 0.398 & 0.428 & 0.453 & 0.458 & 0.460 \\
\hline AG 1: $\{\mathrm{H}\}$ & 0.354 & 0.385 & 0.415 & 0.423 & 0.424 \\
\hline AG 2: $\{\mathrm{H}, \mathrm{EDU}\}$ & 0.338 & 0.360 & 0.390 & 0.395 & 0.396 \\
\hline $\mathrm{AG} 3:\{\mathrm{H}, \mathrm{EDU}, \mathrm{IND}\}$ & 0.321 & 0.348 & 0.379 & 0.387 & 0.388 \\
\hline AG 4: $\{\mathrm{H}, \mathrm{EDU}, \mathrm{IND}, \mathrm{HH}\}$ & 0.312 & 0.342 & 0.374 & 0.381 & 0.383 \\
\hline AG 5: $\{\mathrm{H}, \mathrm{EDU}, \mathrm{IND}, \mathrm{HH}, \mathrm{STATE}\}$ & 0.306 & 0.336 & 0.369 & 0.377 & 0.379 \\
\hline AG 6: $\{\mathrm{EDU}\}$ & 0.378 & 0.398 & 0.422 & 0.424 & 0.426 \\
\hline AG $7:\{\mathrm{H}, \mathrm{IND}, \mathrm{HH}, \mathrm{STATE}\}$ & 0.323 & 0.359 & 0.393 & 0.403 & 0.403 \\
\hline
\end{tabular}

Notes: The responsibility sets include hours worked $\{\mathrm{H}\}$, educational attainment $\{\mathrm{EDU}\}$, industry fixed effects $\{$ IND $\}$, household characteristics $\{\mathrm{HH}\}$, and State fixed effects and metropolitan area $\{$ STATE $\}$. 
status and number of children, $\mathrm{AG} 4$ : $\{\mathrm{H}, \mathrm{EDU}, \mathrm{IND}, \mathrm{HH}\}$ ), and finally their geographical location (AG 5: $\{\mathrm{H}, \mathrm{EDU}, \mathrm{IND}, \mathrm{HH}, \mathrm{STATE}\}$ ) explains additional portions of the inequality measure. Taking all these factors into account, and attributing them towards one's responsibility, produces an adjusted Gini of 0.38, as displayed in Table 3. In absolute terms, the raw Gini has increased by 6.2 index points since the late 1960s (from 0.398 to 0.46 ), whereas the AG 5 has increased by 7.3 index points (from 0.306 to 0.379 ). This suggests that unfair inequality has increased even more than raw inequality since 1967. In relative terms, the raw Gini has increased by 15.6 percent, whereas the AG 5 is 23.9 percent higher today than in the late $1960 \mathrm{~s}$. Thus, considering absolute or relative changes in (adjusted) inequality both leads to the conclusion that the "unfair" portion of inequality has been rising. This is true regardless of the responsibility set that is chosen.

Within these adjusted Ginis, looking at the individual net contributions of certain variables can produce telling stories, as displayed in the right graph of Figure 2. (These contributions are calculated from differences in successive rows that are displayed for some years in Table 3, representing the marginal reduction in the Gini coefficient from each new set of variables included in the responsibility set.) For instance, the contribution of hours worked to inequality has been marginally decreasing since the early 1980s, but the most significant developments relate to educational attainment and industry of employment. Until the early 1980s, industry was a stronger contributor towards inequality, but both industry and education were relatively constant predictors of inequality. However, in the early 1980s both factors took opposing turns. Whereas the industry of employment began to explain less and less of income inequality, displayed by the negative slope, education consistently played a bigger role, confirming previous findings by Lemieux (2006a). In fact, relative to the entire portion of inequality that our variables can explain (i.e., using our largest responsibility set, AG 5), the share of education more than doubled from about 15 percent in the mid 1970s to over 35 percent in 2012. Thus, not only is education leading to bigger wages today relative to 45 years ago, but it also explains more of inequality. Beyond that, the remaining variables of household characteristics and geographical location show only minor changes in their explanatory power of inequality over time, after education and industry have already been added to the responsibility set.

Inferring the role of particular variables by comparison of successive adjusted Ginis is reliant 
on the order that variables are added to the responsibility set. Since some argument could be made for alternative orderings of variables in our successive adjusted Ginis, we produce two additional adjusted Ginis to further highlight the role of educational attainment, shown in the final rows of Table 3. First, the AG 6 only includes educational attainment into the responsibility set. Thus, the displayed Ginis in that row only show inequality stemming from all other factors, but not from education. In other words, we assume here that people are only held responsible for their education. The difference of the AG 6 to the raw Gini then signals the degree to which education can explain income inequality. Notice that this portion went from 2 index points in 1969 (0.398 minus 0.378) to 3.4 index points in 2012 (0.46 minus 0.426). Further, the AG 7 does exactly the opposite by holding people accountable for all other factors (hours worked, job industry, household characteristics, and geography), but not for education. Here we can see that the explanatory power of the remaining factors has decreased from 7.5 index points in 1969 to 5.7 index points. Thus, education is explaining substantially more of income inequality today than in the late 1960s, but the other explanatory variables used here are explaining less.

From these overall developments in the sources of inequality, we now turn to trends in adjusted inequality within gender and racial groups.

\subsection{Fair and Unfair Inequality within Gender and Race}

Figure 3 displays the raw Gini and all five categories of adjusted Ginis for females (solid line) and males (dashed line). First, although raw inequality within gender has been increasing for both females and males, the slope has been steeper for men. In 1969, pure wage inequality among men is described by a Gini coefficient of 0.34 , but this number has since increased to almost 0.46 in 2012, corresponding to a 0.12 point increase on the Gini scale. The comparable rise for women is only 0.05 , from 0.39 to about 0.44 . Thus, a major portion of the rise in inequality in the United States seems to be happening among men. In fact, inequality among women was higher than inequality among men in 1969, but today this relationship has reversed.

Sequentially adding our five categories of responsibility factors continues this trend within the estimated adjusted Ginis. However, we note a couple of particularities. For instance, consider the crossing point, where inequality among men becomes bigger than inequality among women. In the raw Gini, this point is reached in 1990. However, when acknowledging responsibility for 
Raw Gini

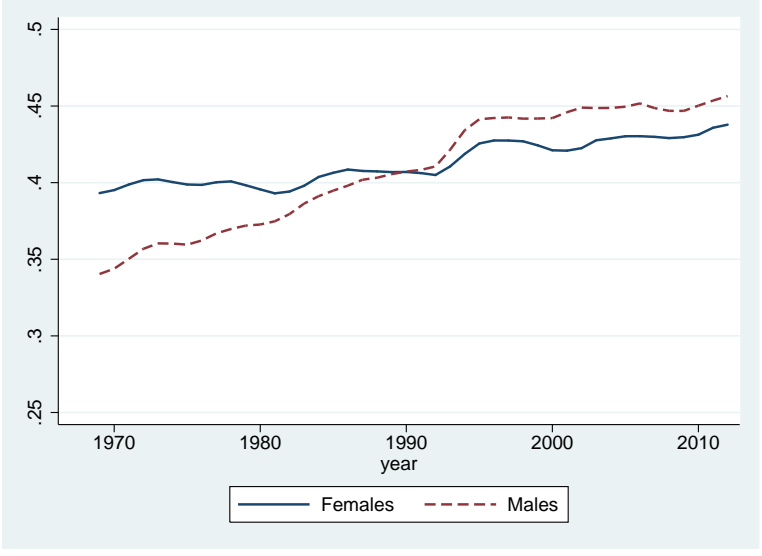

AG 2: $\{\mathrm{H}, \mathrm{EDU}\}$

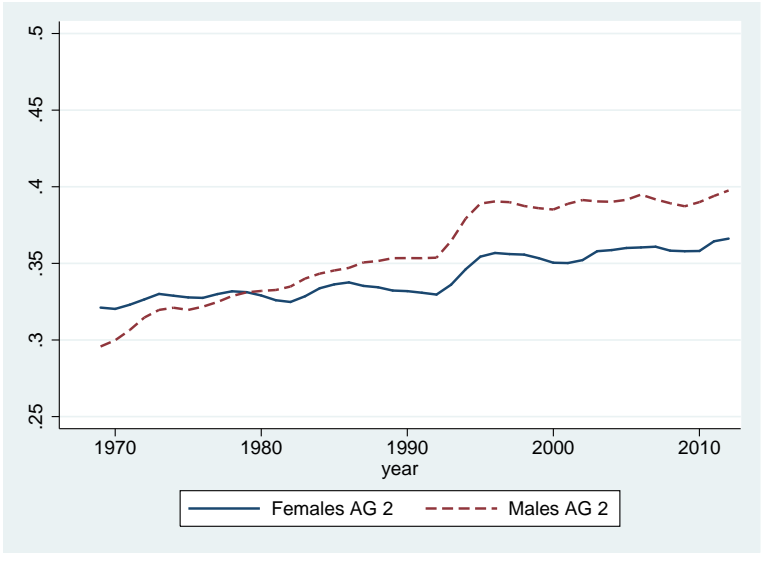

AG 4: $\{\mathrm{H}, \mathrm{EDU}, \mathrm{IND}, \mathrm{HH}\}$

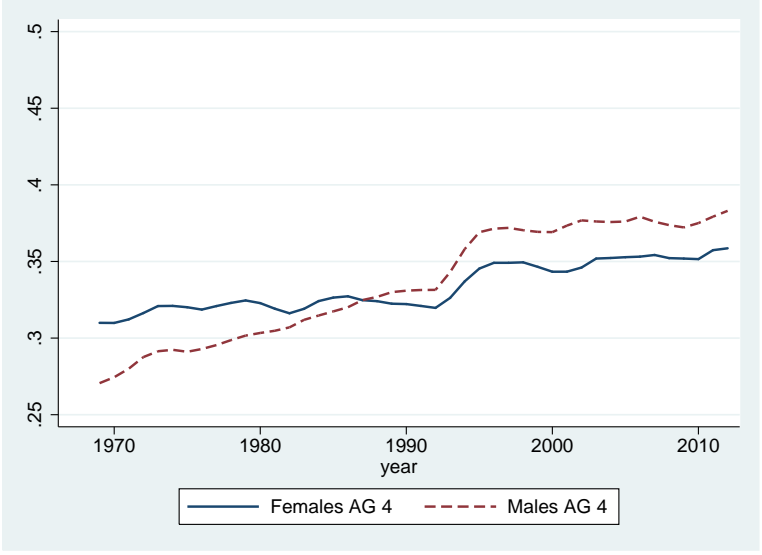

AG 1: $\{\mathrm{H}\}$

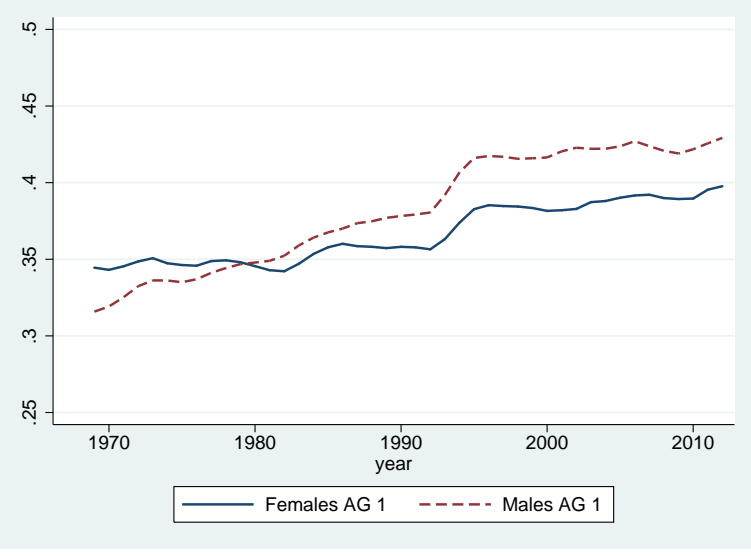

AG 3: $\{\mathrm{H}, \mathrm{EDU} . \mathrm{IND}\}$

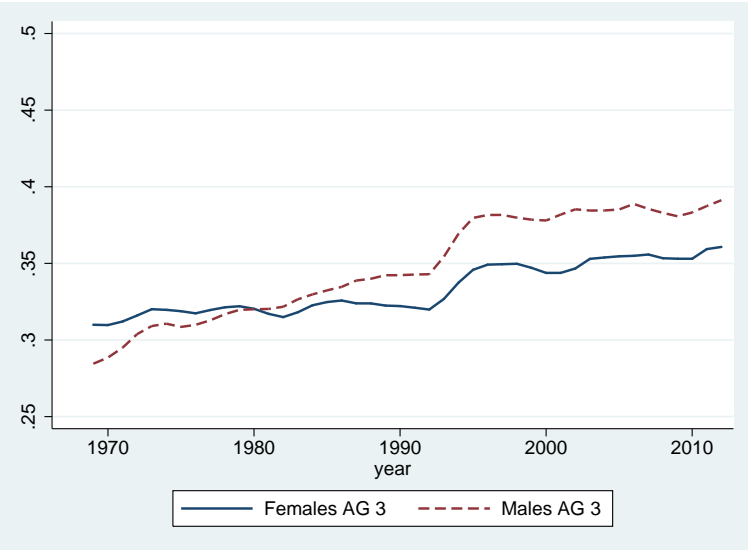

AG 5: $\{\mathrm{H}, \mathrm{EDU}, \mathrm{IND}, \mathrm{HH}, \mathrm{STATE}\}$

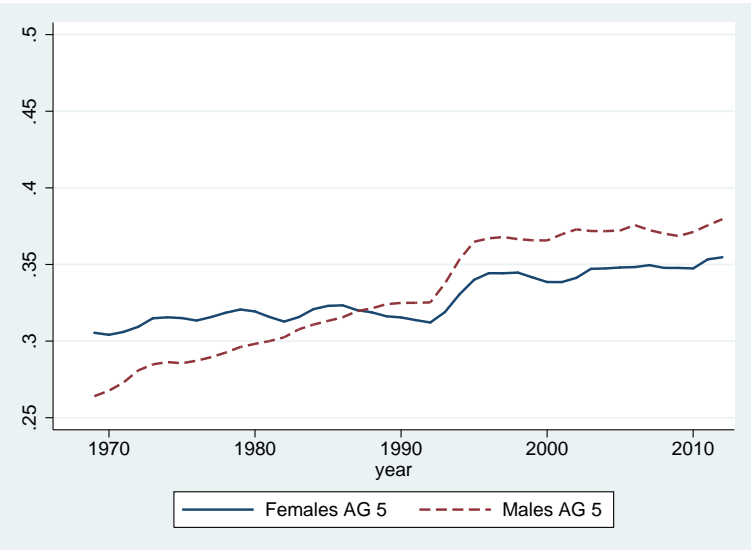

Figure 3: Inequality among females and males over time, where AG 1 includes hours worked $(\{\mathrm{H}\}) ; \mathrm{AG} 2$ adds educational attainment $(\{\mathrm{H}, \mathrm{EDU}\}) ; \mathrm{AG} 3$ adds industry fixed effects $(\{\mathrm{H}, \mathrm{EDU}, \mathrm{IND}\}) ; \mathrm{AG} 4$ adds household characteristics $(\{\mathrm{H}, \mathrm{EDU}, \mathrm{IND}$, $\mathrm{HH}\})$; AG 5 adds state fixed effects and metropolitan area $(\{\mathrm{H}, \mathrm{EDU}, \mathrm{IND}, \mathrm{HH}$, STATE $\}$ ). 
hours worked, this point occurs in 1980. Thus, inequality adjusted for time spent at work has been higher among men than among women since 1980. Notice also that for the AG 1, AG 2, and AG 3, the gap between both gender-specific Ginis becomes bigger in recent years, whereas this gap seems to be closing for the AG 4 and then for the AG 5. Interestingly, this suggests that hours worked, educational attainment, and job industry are able to explain inequality among women better than among men. In turn, household characteristics, such as marital status and number of children, are better able to explain wage inequality among men, than wage inequality among women.

Figure 4 then considers differences in overall and unfair inequality within races, using the two most represented ethnic groups of our sample: blacks and whites. Raw income inequality was remarkably similar across the two groups in the late 1960s (with a Gini coefficient of 0.39). It has also increased for both races since 1969, but substantially more so among whites (top left graph). As measured by the Gini coefficient, the wage disparity within whites has increased by seven index points to 0.46 , but within blacks this rise only consisted of three index points to 0.42 . This basic trend remains the same throughout all adjusted Ginis and the general conclusions regarding the individual variables derived in the main analysis hold for both blacks and whites. One notable difference, however, lies in the marginal reduction in the adjusted Gini in the early years of our sample when U.S. state of residence is added to the responsibility set. This reduction occurs almost entirely among blacks and not among whites, suggesting a non-trivial amount of overall inequality among blacks in the past is described by geographic location (likely northern versus southern states).

Figures 5 and 6 then distinguish within blacks and whites by gender. First, inequality among black males was substantially lower than among black females in 1969 (0.34 versus 0.42), but then wage disparities within black males started to rise strongly since the mid 1970s. This observation is consistent with the general trend from Figure 3. However, the data reveal an interesting particularity here for black females, as inequality within this group today is actually lower than in 1969 (0.41 versus 0.42). This finding does not hold, however, once we allow hours worked and especially educational attainment to reflect fair inequality. This serves as an example of where deriving the adjusted Gini can lead to a different conclusion than considering the raw Gini alone. If we accept at least hours worked as a responsibility factor, then unfair inequality 
Raw Gini

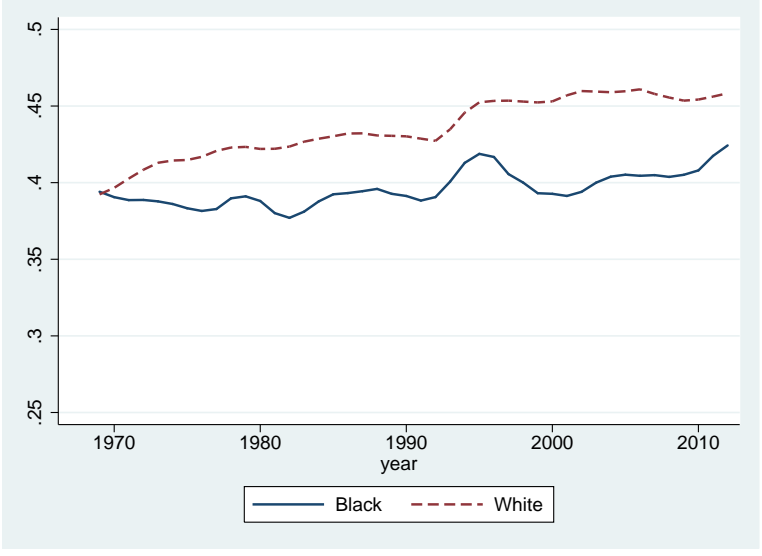

AG 2: $\{\mathrm{H}, \mathrm{EDU}\}$

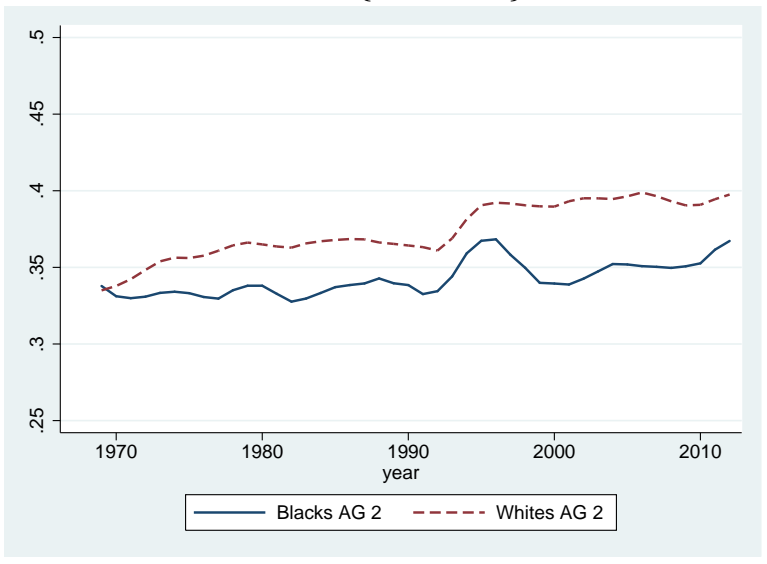

AG 4: $\{\mathrm{H}, \mathrm{EDU}, \mathrm{IND}, \mathrm{HH}\}$

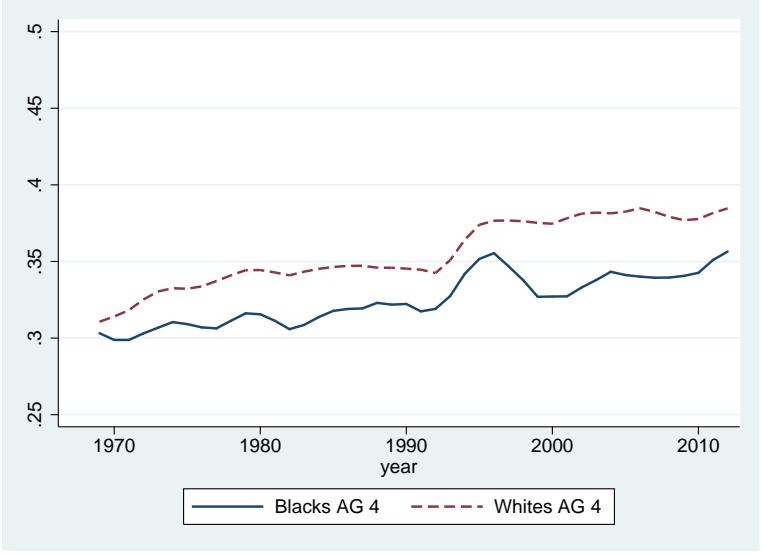

AG 1: $\{\mathrm{H}\}$

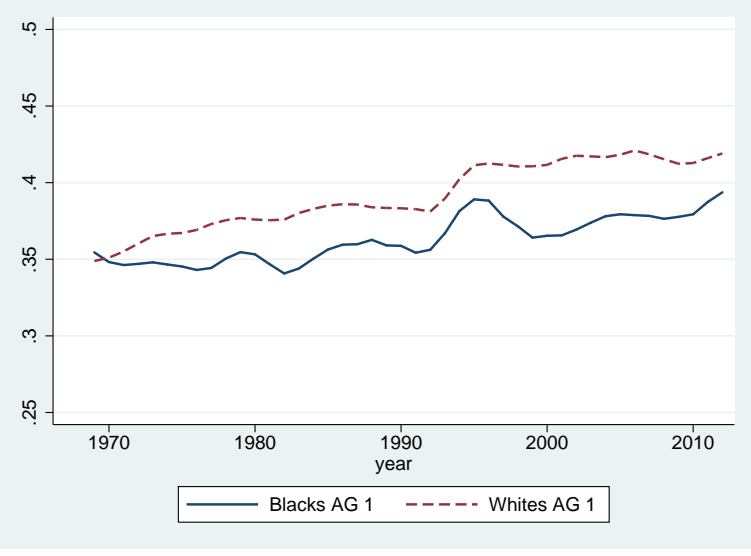

AG 3: $\{\mathrm{H}, \mathrm{EDU}, \mathrm{IND}\}$

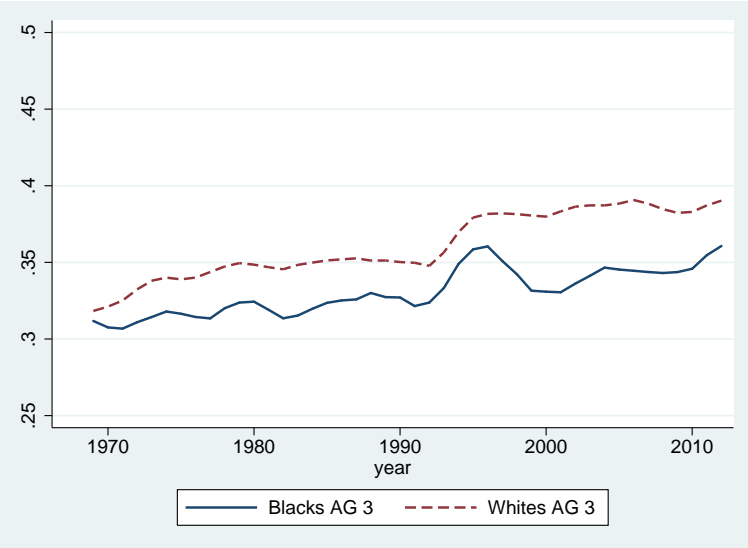

AG 5: $\{\mathrm{H}, \mathrm{EDU}, \mathrm{IND}, \mathrm{HH}, \mathrm{STATE}\}$

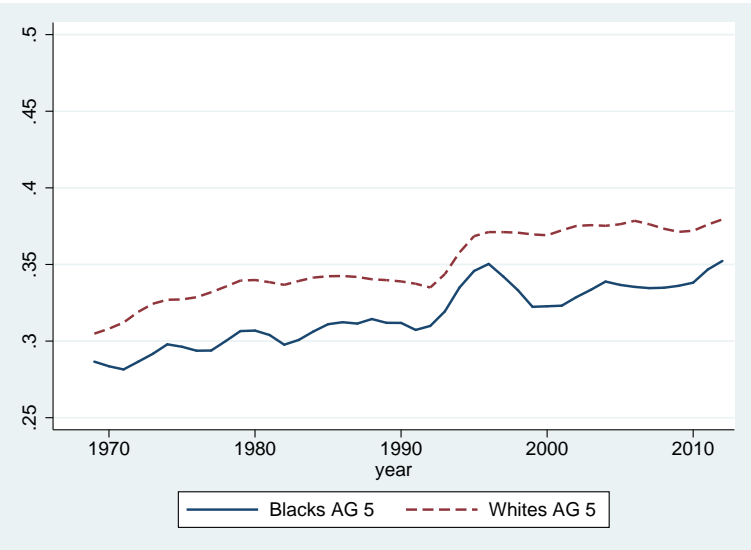

Figure 4: Inequality among blacks and whites over time, where AG 1 includes hours worked $(\{\mathrm{H}\}) ; \mathrm{AG} 2$ adds educational attainment $(\{\mathrm{H}, \mathrm{EDU}\}) ; \mathrm{AG} 3$ adds industry fixed effects $(\{\mathrm{H}, \mathrm{EDU}, \mathrm{IND}\}) ; \mathrm{AG} 4$ adds household characteristics $(\{\mathrm{H}, \mathrm{EDU}, \mathrm{IND}$, $\mathrm{HH}\})$; AG 5 adds state fixed effects and metropolitan area $(\{\mathrm{H}, \mathrm{EDU}, \mathrm{IND}, \mathrm{HH}$, STATE $\}$ ). 
within black women is higher today than in 1969, even though the traditional Gini would lead us to believe the opposite. Adjusting for the remaining sets of variables further solidifies this conclusion.

Moving to inequalities by gender for white respondents in Figure 6 shows trends in inequality and adjusted inequality measures that closely resemble the basic gender results from Figure 3. This is not surprising, given that the majority of individuals in the CPS are whites. Thus, inequality among white males has been higher than among white females until the early 1990s, but since then we observe marginally more income inequality among men. Once working hours are accounted for, the gap between the adjusted Ginis for women and men becomes bigger, suggesting that the time spent working explains relatively more of inequality among women than among men. Also notice that household characteristics are able to explain a larger portion for wage inequality among males. Overall, however, the main takeaway from Figure 6 is the strong rise in inequality among men, whereas inequality among women has only been rising modestly since the 1970s.

From looking at wage inequality by gender and race, we now turn to developments in inequality across geographic regions.

\subsection{Fair and Unfair Inequality within States}

Considering regional differences of inequality developments is especially important for a large and diverse country like the United States. Not only due to its large geographical size, but also because of its history as a country of immigrants from a variety of cultural and historical backgrounds, a more detailed analysis is justified here. As a first approach, we follow the CPS definitions and analyze inequality for four U.S. regions: the Northeast, the Midwest, the South, and the West. ${ }^{8}$ Although reducing the sample into four distinct regions appears crude, the resulting estimates already allow us to draw some interesting conclusions from comparisons of the basic Gini and the adjusted Ginis by regions (Figure 7). A general result is that inequality (raw

\footnotetext{
${ }^{8}$ Northeast: Connecticut, Maine, Massachusetts, New Hampshire, New Jersey, New York, Pennsylvania, Rhode Island, and Vermont. Midwest: Illinois, Indiana, Iowa, Kansas, Michigan, Minnesota, Missouri, Nebraska, North Dakota, Ohio, South Dakota, and Wisconsin. South: Alabama, Arkansas, Delaware, District of Columbia, Florida, Georgia, Kentucky, Louisiana, Maryland, Mississippi, North Carolina, Oklahoma, South Carolina, Tennessee, Texas, Virginia, West Virginia. West: Alaska, Arizona, California, Colorado, Hawaii, Idaho, Montana, Nevada, New Mexico, Oregon, Utah, Washington, and Wyoming.
} 
Raw Gini

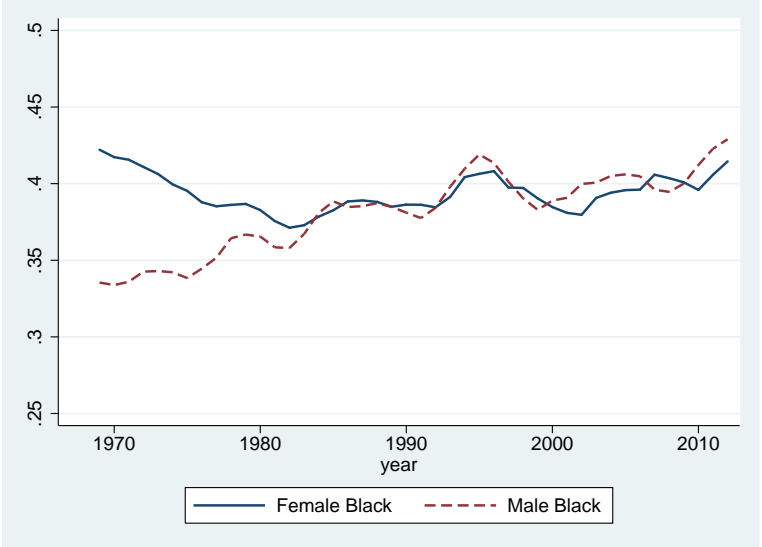

AG 2: $\{\mathrm{H}, \mathrm{EDU}\}$

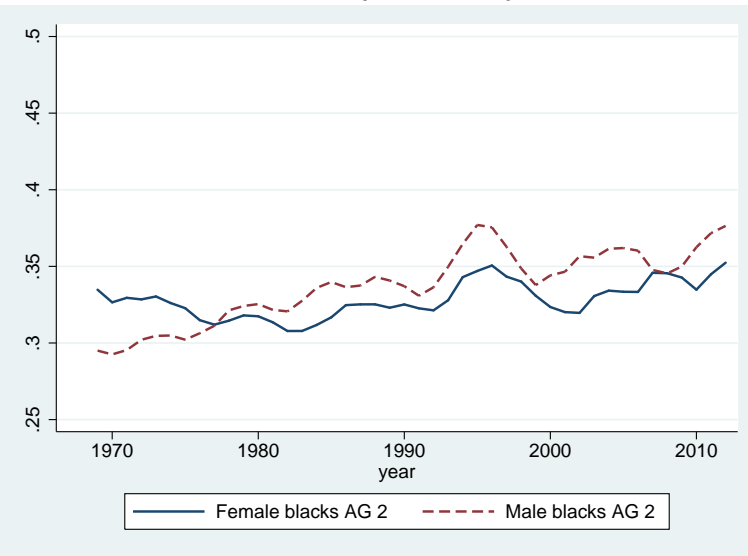

AG 4: $\{\mathrm{H}, \mathrm{EDU}, \mathrm{IND}, \mathrm{HH}\}$

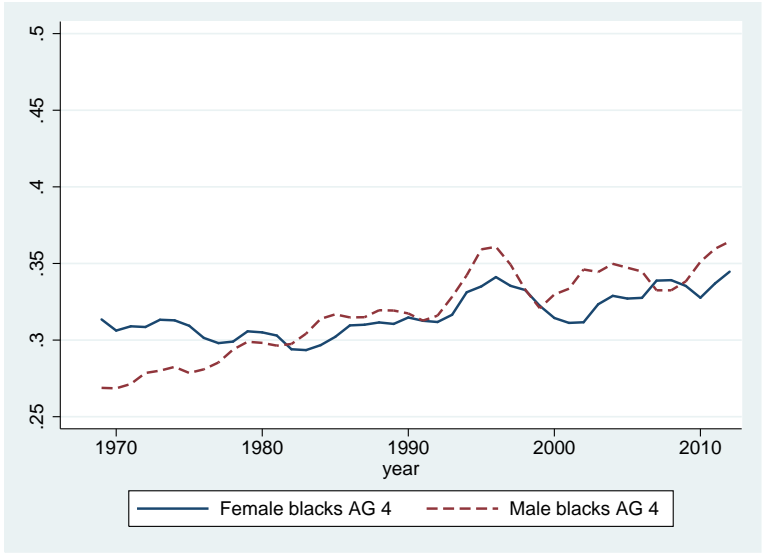

AG 1: $\{\mathrm{H}\}$

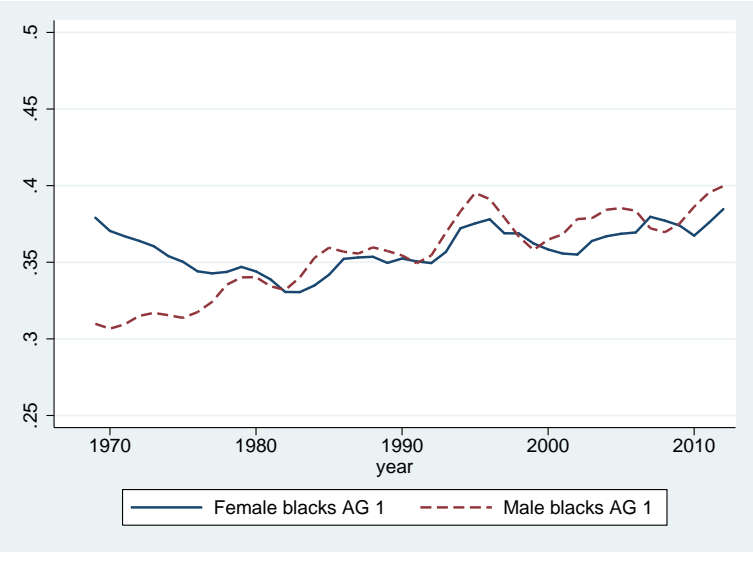

AG 3: $\{\mathrm{H}, \mathrm{EDU}, \mathrm{IND}\}$

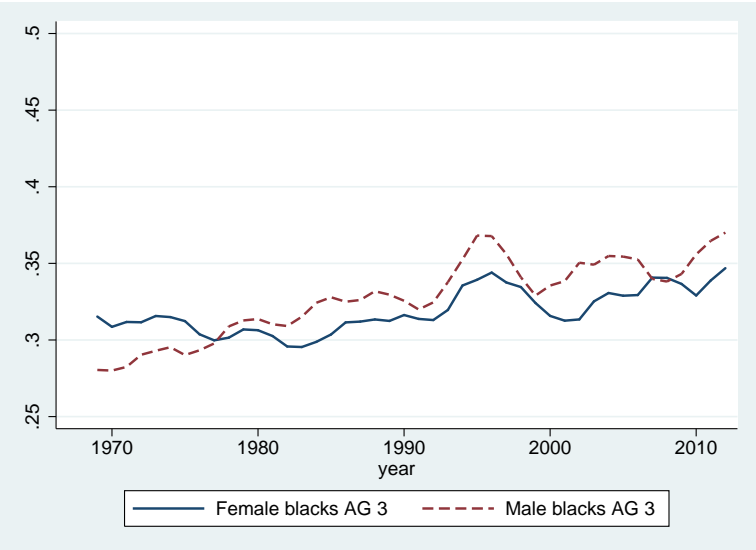

AG 5: $\{\mathrm{H}, \mathrm{EDU}, \mathrm{IND}, \mathrm{HH}, \mathrm{STATE}\}$

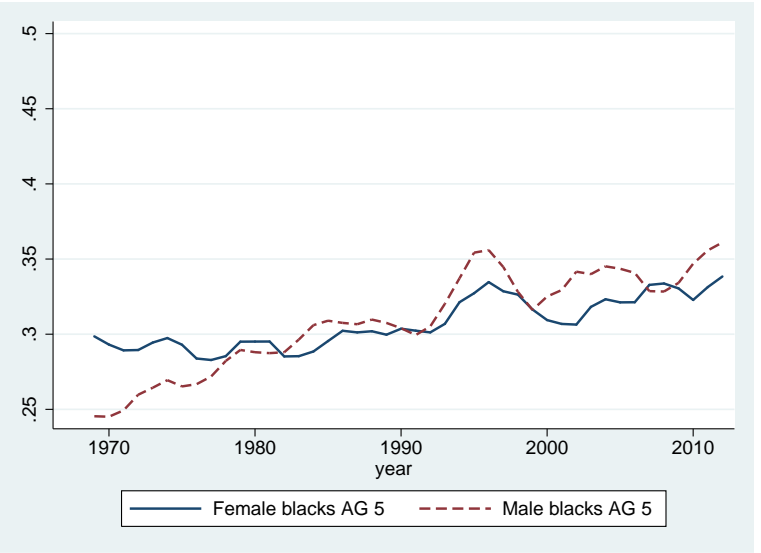

Figure 5: Gender differences in inequality among blacks, where AG 1 includes hours worked $(\{\mathrm{H}\})$; AG 2 adds educational attainment ( $\{\mathrm{H}, \mathrm{EDU}\}) ; \mathrm{AG} 3$ adds industry fixed effects $(\{\mathrm{H}, \mathrm{EDU}, \mathrm{IND}\}) ; \mathrm{AG} 4$ adds household characteristics $(\{\mathrm{H}, \mathrm{EDU}, \mathrm{IND}$, $\mathrm{HH}\})$; AG 5 adds state fixed effects and metropolitan area $(\{\mathrm{H}, \mathrm{EDU}, \mathrm{IND}, \mathrm{HH}$, STATE $\}$ ). 
Raw Gini

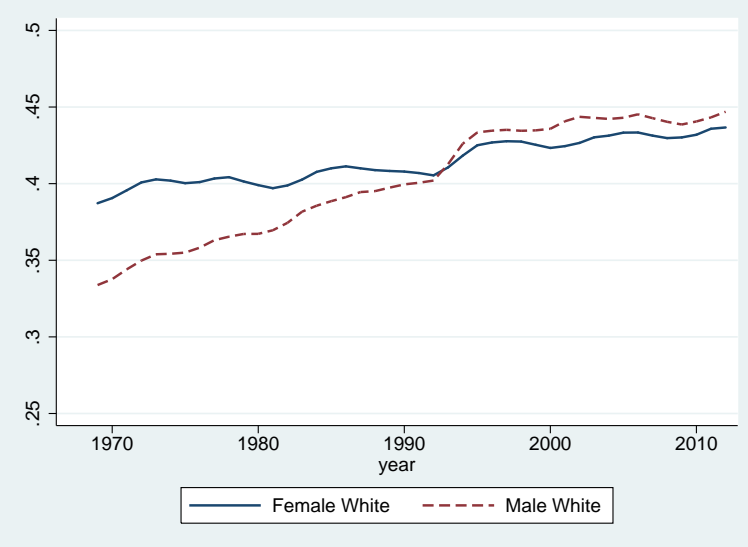

AG 2: $\{\mathrm{H}, \mathrm{EDU}\}$

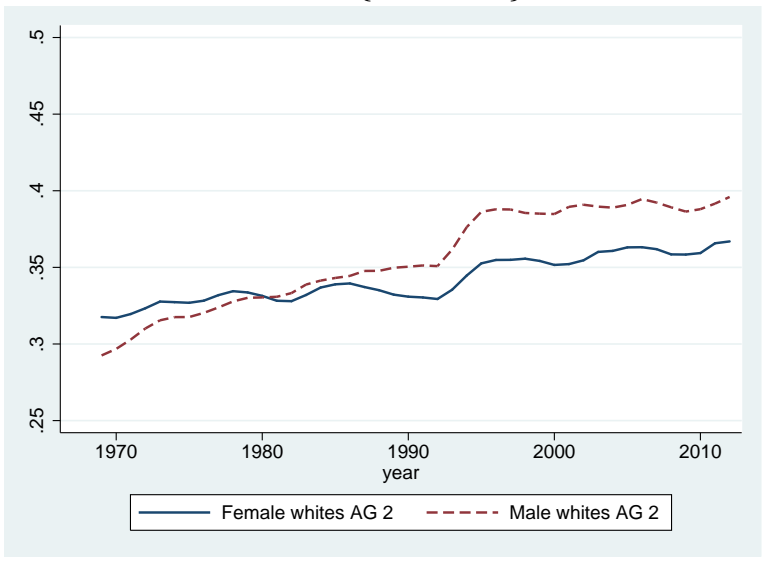

AG 4: $\{\mathrm{H}, \mathrm{EDU}, \mathrm{IND}, \mathrm{HH}\}$

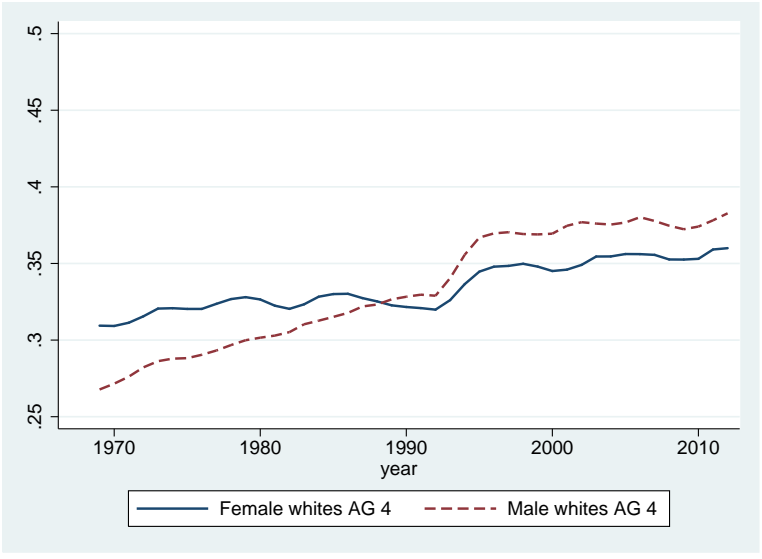

AG 1: $\{\mathrm{H}\}$

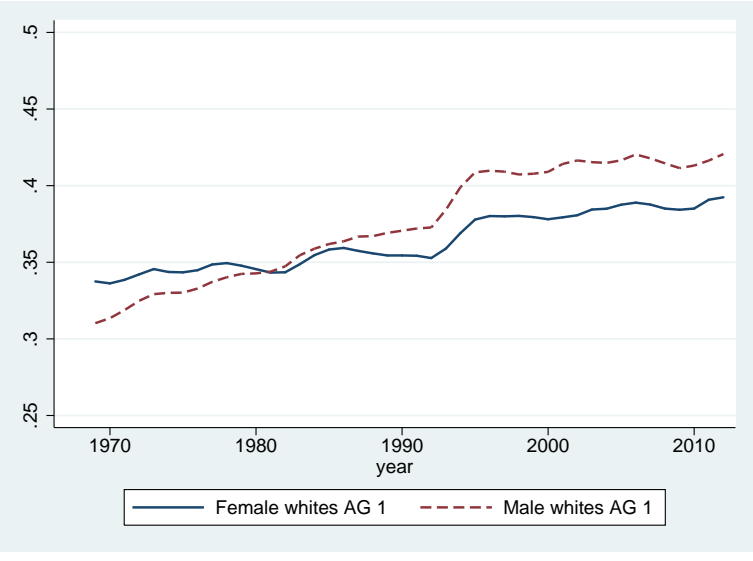

AG 3: $\{\mathrm{H}, \mathrm{EDU}, \mathrm{IND}\}$

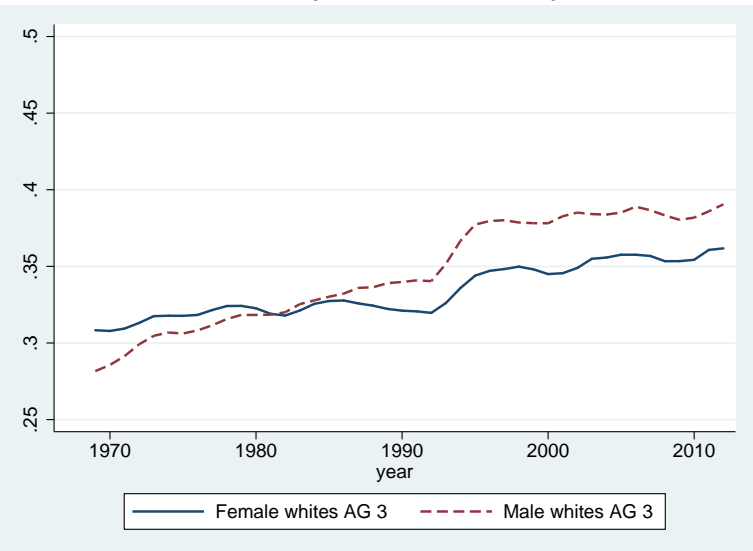

AG 5: $\{\mathrm{H}, \mathrm{EDU}, \mathrm{IND}, \mathrm{HH}, \mathrm{STATE}\}$

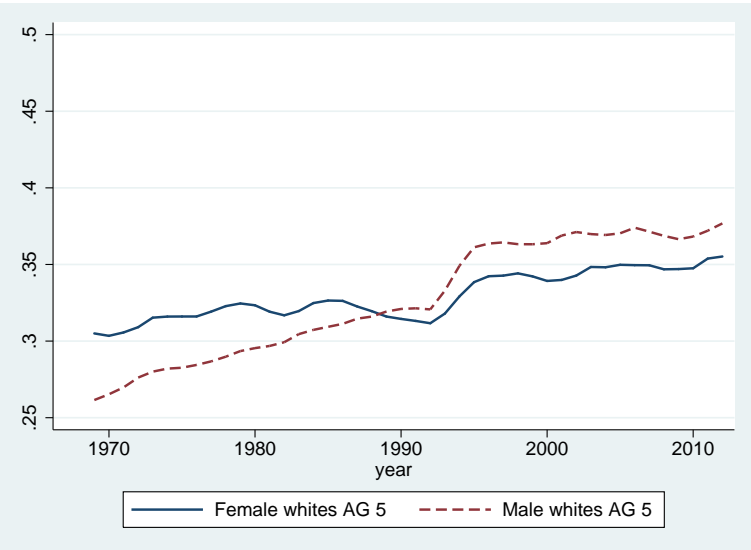

Figure 6: Gender differences in inequality among whites, where AG 1 includes hours worked $(\{\mathrm{H}\}) ; \mathrm{AG} 2$ adds educational attainment $(\{\mathrm{H}, \mathrm{EDU}\}) ; \mathrm{AG} 3$ adds industry fixed effects ( $\{\mathrm{H}, \mathrm{EDU}, \mathrm{IND}\}) ; \mathrm{AG} 4$ adds household characteristics $(\{\mathrm{H}, \mathrm{EDU}, \mathrm{IND}$, $\mathrm{HH}\})$; AG 5 adds state fixed effects and metropolitan area $(\{\mathrm{H}, \mathrm{EDU}, \mathrm{IND}, \mathrm{HH}$, STATE $\}$ ). 
Raw Gini

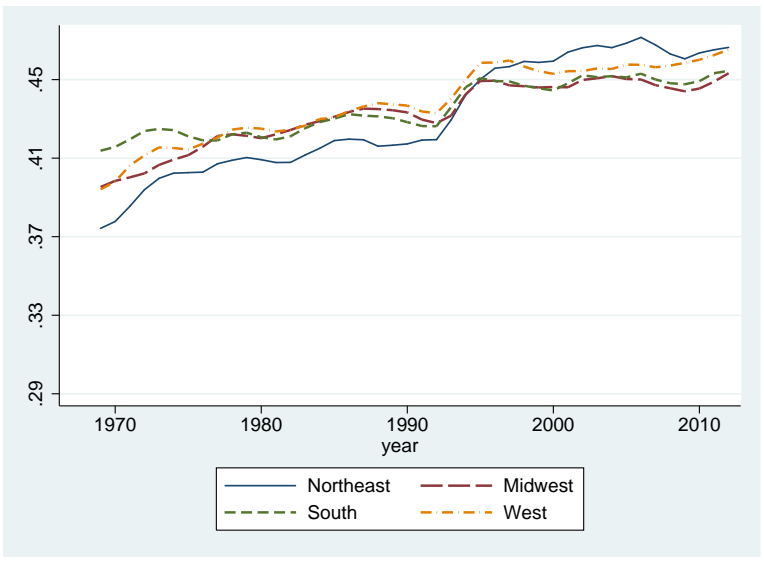

AG 2: $\{\mathrm{H}, \mathrm{EDU}\}$

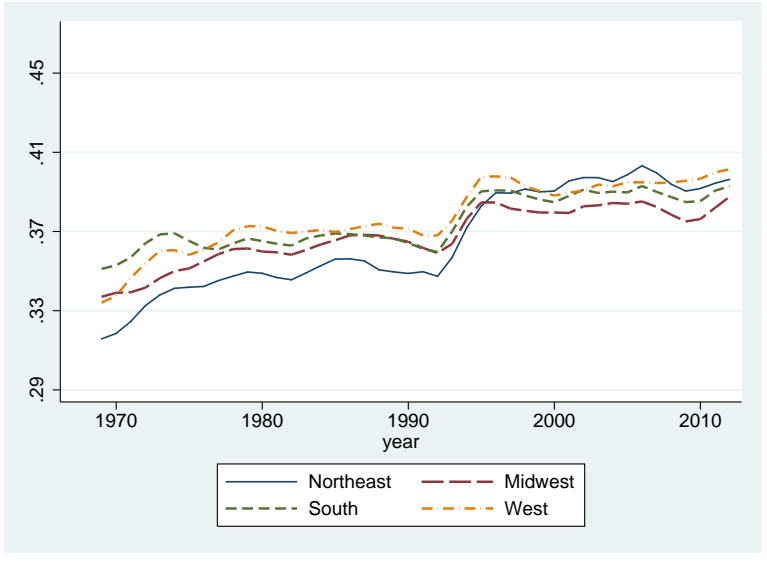

AG 4: $\{\mathrm{H}, \mathrm{EDU}, \mathrm{IND}, \mathrm{HH}\}$

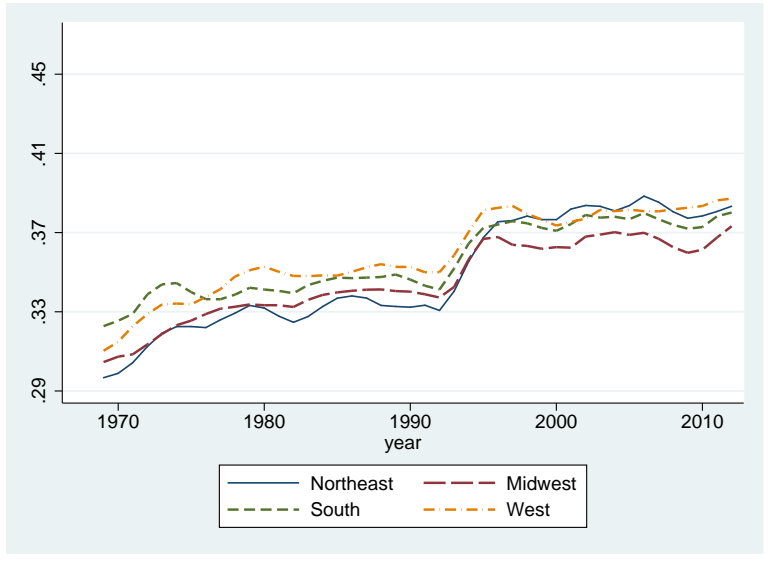

AG 1: $\{\mathrm{H}\}$

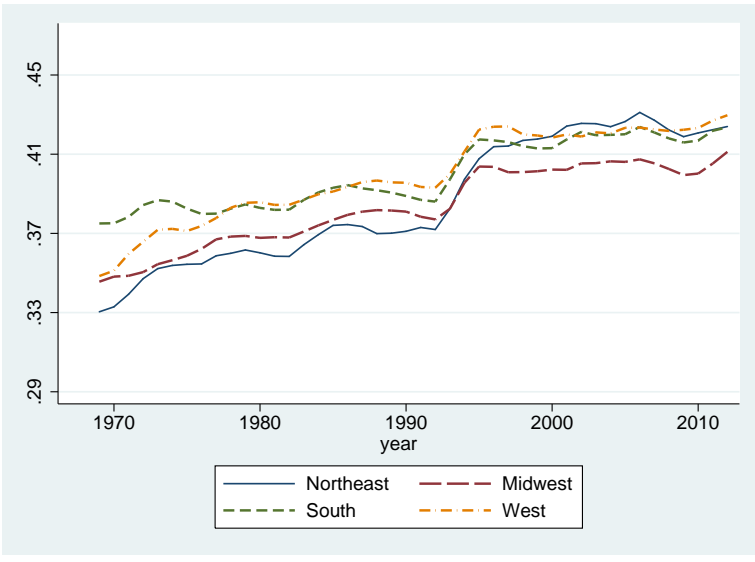

AG 3: $\{\mathrm{H}, \mathrm{EDU}, \mathrm{IND}\}$

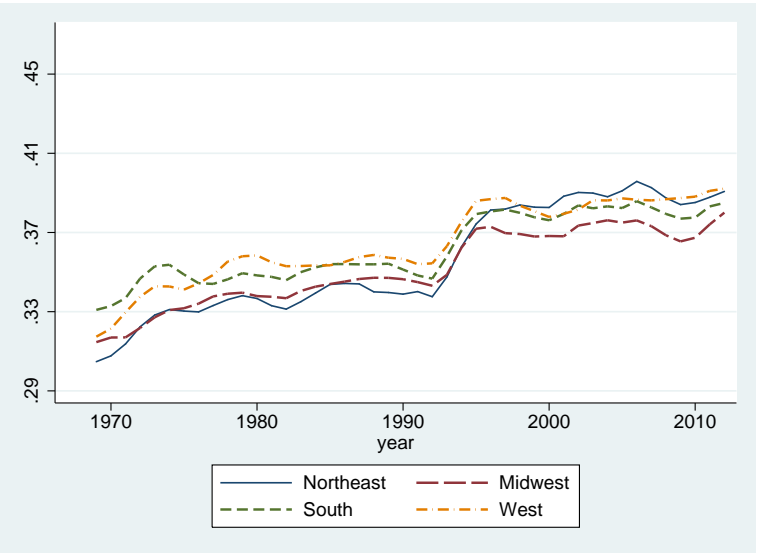

AG 5: $\{\mathrm{H}, \mathrm{EDU}, \mathrm{IND}, \mathrm{HH}, \mathrm{STATE}\}$

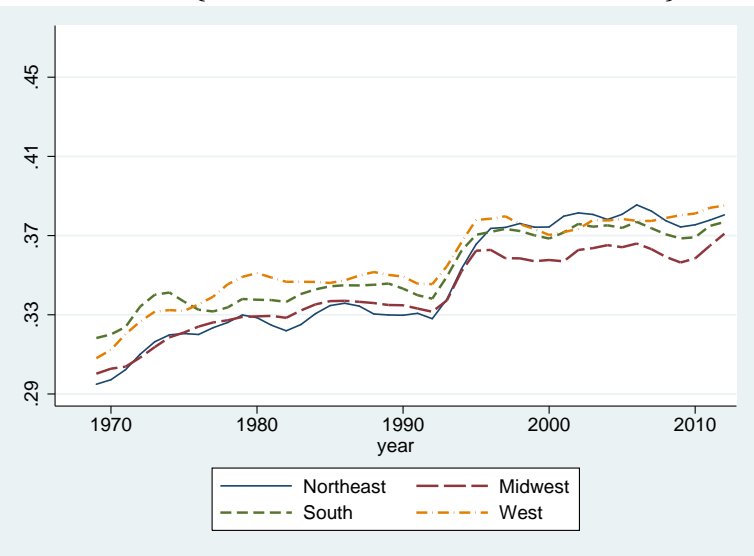

Figure 7: Regional differences in inequality over time, where AG 1 includes hours worked $(\{\mathrm{H}\}) ; \mathrm{AG} 2$ adds educational attainment $(\{\mathrm{H}, \mathrm{EDU}\}) ; \mathrm{AG} 3$ adds industry fixed effects $(\{\mathrm{H}, \mathrm{EDU}, \mathrm{IND}\}) ; \mathrm{AG} 4$ adds household characteristics $(\{\mathrm{H}, \mathrm{EDU}, \mathrm{IND}$, $\mathrm{HH}\})$; AG 5 adds state fixed effects and metropolitan area $(\{\mathrm{H}, \mathrm{EDU}, \mathrm{IND}, \mathrm{HH}$, STATE $\}$ ). 
and adjusted) has increased in all regions, but the steepest rise has occurred in the Northeast. The inclusion of all our potential responsibility factors can explain almost 20 percent of inequality in the Northeastern region (as the raw Gini drops from 0.47 to 0.38 ), and the explanatory effect of these variables is similar for the remaining three regions. In 1969, this area was the most equal in terms of wages, but today we observe the strongest wage disparities in the Northeast. Adding variables to the set of responsibility factors marginally closes this gap, but the general conclusion remains.

Given the size of the CPS sample, we are also able to consider inequality within particular U.S. states and their development over time. For this analysis, we restrict the sample to after 1976, since before that time not all states were separately identified in the CPS, and the groupings of individual states also changed across years. In this context, Figure 8 shows two maps displaying the raw Ginis in 1976 - 1978 and 2010 - 2012. With darker shades implying higher inequality, we can immediately notice that a large majority of U.S. states experienced a rise in raw inequality over the past 35 years. However, some states also exhibit less or the same wage inequality today (e.g. South Dakota), relative to the late 1970s. Table 4 provides a complete list of inequality trends by state.

Figure 9 then highlights the development over time for the adjusted Ginis. Displaying three different versions of the Gini (raw Gini, AG 3, and AG 5), states are color coded by their change in the adjusted Gini from the beginning (1976) to the end (2012) of this subsample. States in light blue have experienced a decrease in wage disparity towards a more equal distribution of earnings, while yellow and red represent small and large increases in the Gini within the state. The top map shows that the raw Gini has actually decreased in eight states (Delaware, Minnesota, Montana, Nebraska, North Dakota, Oklahoma, South Dakota, and Wyoming). Thus, although the trend towards more wage inequality can be observed in the majority of the U.S. states, this conclusion does not hold everywhere. Regional differences in terms of inequality developments over time within the U.S. (raw Gini and adjusted Ginis) exist - something that has recently been highlighted for France (Carpantier and Sapata, 2012). We do observe a particularly strong increase of raw inequality (a rise in the Gini by over 0.05 index points) in the Northeastern states, California, and New Mexico.

The second map then acknowledges hours worked, educational attainment, and the job in- 

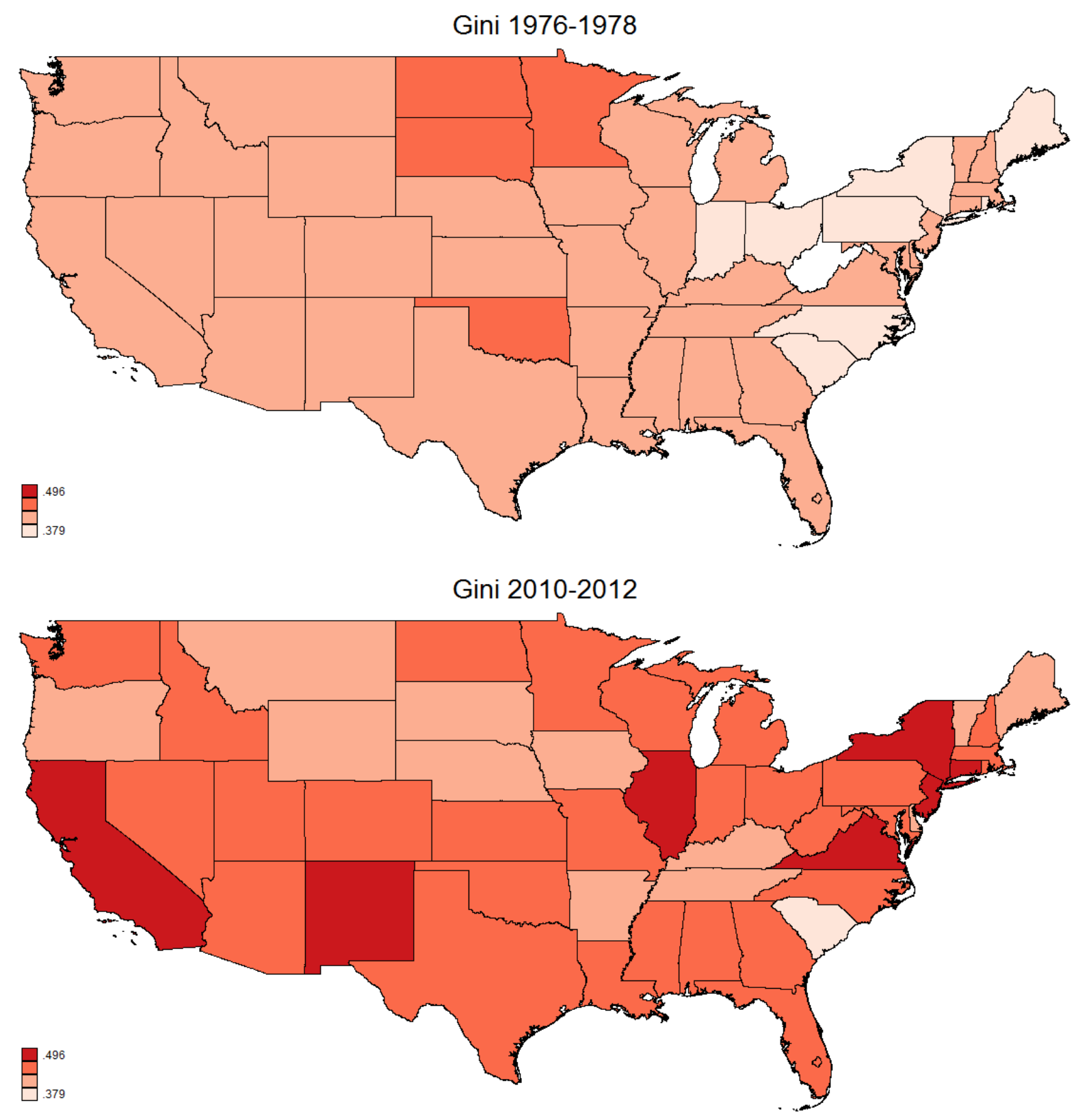

Figure 8: Raw Gini in 1976 - 1978 (top) versus 2010 - 2012 (bottom) 
Table 4: Ginis by States.

\begin{tabular}{|c|c|c|c|c|c|c|}
\hline \multirow[b]{2}{*}{ State } & \multicolumn{2}{|c|}{ Raw Gini } & \multicolumn{2}{|c|}{$\begin{array}{c}\text { AG 3 } \\
\{\mathrm{H}, \mathrm{EDU}, \mathrm{IND}\}\end{array}$} & \multicolumn{2}{|c|}{$\begin{array}{c}\text { AG } 5 \\
\{\mathrm{H}, \mathrm{EDU}, \mathrm{IND}, \mathrm{HH}, \mathrm{STATE}\}\end{array}$} \\
\hline & $1976-1978$ & 2010-2012 & $1976-1978$ & $2010-2012$ & $1976-1978$ & 2010-2012 \\
\hline Alabama & 0.42 & 0.44 & 0.35 & 0.36 & 0.34 & 0.35 \\
\hline Alaska & 0.43 & 0.43 & 0.37 & 0.36 & 0.37 & 0.35 \\
\hline Arizona & 0.43 & 0.46 & 0.37 & 0.39 & 0.36 & 0.39 \\
\hline Arkansas & 0.41 & 0.43 & 0.33 & 0.37 & 0.33 & 0.36 \\
\hline California & 0.42 & 0.49 & 0.35 & 0.41 & 0.34 & 0.40 \\
\hline Colorado & 0.43 & 0.47 & 0.36 & 0.39 & 0.35 & 0.38 \\
\hline Connecticut & 0.42 & 0.50 & 0.33 & 0.41 & 0.32 & 0.41 \\
\hline Delaware & 0.43 & 0.42 & 0.33 & 0.35 & 0.33 & 0.34 \\
\hline District of Columbia & 0.39 & 0.46 & 0.31 & 0.39 & 0.31 & 0.39 \\
\hline Florida & 0.42 & 0.45 & 0.35 & 0.39 & 0.34 & 0.39 \\
\hline Georgia & 0.42 & 0.46 & 0.35 & 0.39 & 0.33 & 0.38 \\
\hline Hawaii & 0.38 & 0.44 & 0.31 & 0.38 & 0.31 & 0.37 \\
\hline Idaho & 0.42 & 0.45 & 0.34 & 0.37 & 0.33 & 0.37 \\
\hline Illinois & 0.41 & 0.48 & 0.33 & 0.41 & 0.32 & 0.40 \\
\hline Indiana & 0.39 & 0.44 & 0.31 & 0.37 & 0.30 & 0.37 \\
\hline Iowa & 0.42 & 0.43 & 0.33 & 0.35 & 0.33 & 0.35 \\
\hline Kansas & 0.42 & 0.45 & 0.35 & 0.38 & 0.34 & 0.37 \\
\hline Kentucky & 0.41 & 0.41 & 0.32 & 0.35 & 0.32 & 0.34 \\
\hline Louisiana & 0.42 & 0.44 & 0.35 & 0.38 & 0.34 & 0.37 \\
\hline Maine & 0.40 & 0.43 & 0.34 & 0.36 & 0.34 & 0.36 \\
\hline Maryland & 0.43 & 0.44 & 0.33 & 0.36 & 0.32 & 0.36 \\
\hline Massachusetts & 0.41 & 0.46 & 0.33 & 0.37 & 0.33 & 0.36 \\
\hline Michigan & 0.41 & 0.46 & 0.33 & 0.38 & 0.31 & 0.37 \\
\hline Minnesota & 0.45 & 0.44 & 0.35 & 0.37 & 0.35 & 0.36 \\
\hline Mississippi & 0.42 & 0.44 & 0.35 & 0.39 & 0.34 & 0.38 \\
\hline Missouri & 0.43 & 0.46 & 0.35 & 0.39 & 0.34 & 0.38 \\
\hline Montana & 0.43 & 0.43 & 0.35 & 0.36 & 0.36 & 0.36 \\
\hline Nebraska & 0.44 & 0.43 & 0.35 & 0.36 & 0.35 & 0.36 \\
\hline Nevada & 0.41 & 0.44 & 0.36 & 0.38 & 0.35 & 0.37 \\
\hline New Hampshire & 0.41 & 0.44 & 0.35 & 0.36 & 0.35 & 0.36 \\
\hline New Jersey & 0.42 & 0.49 & 0.34 & 0.41 & 0.34 & 0.40 \\
\hline New Mexico & 0.42 & 0.48 & 0.35 & 0.42 & 0.33 & 0.42 \\
\hline New York & 0.40 & 0.47 & 0.33 & 0.40 & 0.33 & 0.39 \\
\hline North Carolina & 0.40 & 0.46 & 0.33 & 0.39 & 0.32 & 0.38 \\
\hline North Dakota & 0.45 & 0.44 & 0.37 & 0.37 & 0.37 & 0.37 \\
\hline Ohio & 0.40 & 0.46 & 0.33 & 0.38 & 0.32 & 0.37 \\
\hline Oklahoma & 0.44 & 0.44 & 0.35 & 0.39 & 0.34 & 0.38 \\
\hline Oregon & 0.42 & 0.44 & 0.34 & 0.36 & 0.33 & 0.35 \\
\hline Pennsylvania & 0.39 & 0.45 & 0.32 & 0.37 & 0.31 & 0.36 \\
\hline Rhode Island & 0.39 & 0.45 & 0.32 & 0.37 & 0.31 & 0.36 \\
\hline South Carolina & 0.39 & 0.41 & 0.32 & 0.34 & 0.31 & 0.33 \\
\hline South Dakota & 0.47 & 0.42 & 0.38 & 0.37 & 0.38 & 0.36 \\
\hline Tennessee & 0.42 & 0.43 & 0.34 & 0.37 & 0.33 & 0.36 \\
\hline Texas & 0.42 & 0.46 & 0.35 & 0.39 & 0.34 & 0.39 \\
\hline Utah & 0.41 & 0.46 & 0.33 & 0.38 & 0.32 & 0.37 \\
\hline Vermont & 0.43 & 0.43 & 0.34 & 0.37 & 0.33 & 0.36 \\
\hline Virginia & 0.43 & 0.47 & 0.35 & 0.38 & 0.34 & 0.38 \\
\hline Washington & 0.43 & 0.46 & 0.34 & 0.39 & 0.34 & 0.38 \\
\hline West Virginia & 0.38 & 0.44 & 0.31 & 0.37 & 0.31 & 0.37 \\
\hline Wisconsin & 0.42 & 0.44 & 0.31 & 0.36 & 0.31 & 0.35 \\
\hline Wyoming & 0.42 & 0.42 & 0.34 & 0.33 & 0.34 & 0.33 \\
\hline
\end{tabular}


dustry of the individual as part of one's responsibility. Thus, any inequality resulting from these factors is used to calculate the "fair" wage and is not reflected in the AG 3 ( $\{\mathrm{H}, \mathrm{EDU}, \mathrm{IND}\})$. In this case, only South Dakota and Wyoming remain as the states with lower (unfair) wage inequality today, compared to the late 1970s. Notice also that by this standard of responsibility factors, additional states show a stark rise in inequality. In addition to a few western states, these are most concentrated in the Rust belt region around the Great Lakes (extending from Illinois to New York), an area that was most impacted by the deindustrialization occurring in the United States in the 1980s and onward. Finally, the bottom map further adds marital status, number of children, and whether the respondent lives in a metropolitan area to the set of responsibility factors. By this definition of responsibility, we recover North Dakota as a state with decreasing inequality and Florida becomes an area with a stark increase in (unfair) inequality.

The main takeaway from these regional analyses consists in a strong heterogeneity among states in terms of inequality developments over time. In addition, distinguishing between responsibility and non-responsibility factors in their contribution to wage inequality can produce different conclusions in different areas. This further highlights the importance of analyzing the particular sources of income inequality, as these can differ by region. Overall, analyzing inequality within states produces interesting results, providing a more detailed analysis of developments in wage disparities in the United States.

\section{Concluding Remarks and Discussion}

This paper analyzes the determinants of income inequality within the United States over the time period from 1967 to 2012. Using a recently developed methodology by Almås et al. (2011), we employ CPS data to derive not only the raw Gini coefficient, but also adjusted Ginis. Specifically, we derive Gini coefficients following five different definitions of what might reasonably be considered as part of one's own responsibility, subsequently incorporating inequalities stemming from hours worked, educational attainment, job industry, household characteristics, and geographical location. This distinction can be important, especially for policymakers, since potential rules and regulations designed to address income inequality may differ drastically depending on the particular source of income inequality. For instance, wage inequalities arising 


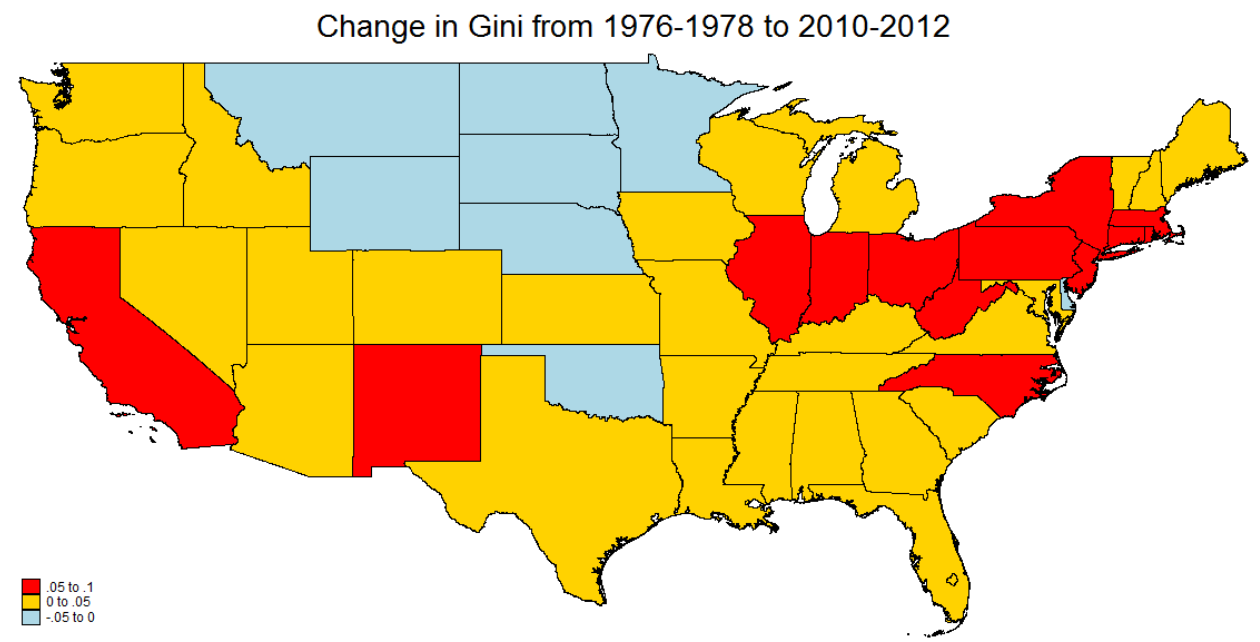

Change in AG 3 from 1976-1978 to 2010-2012

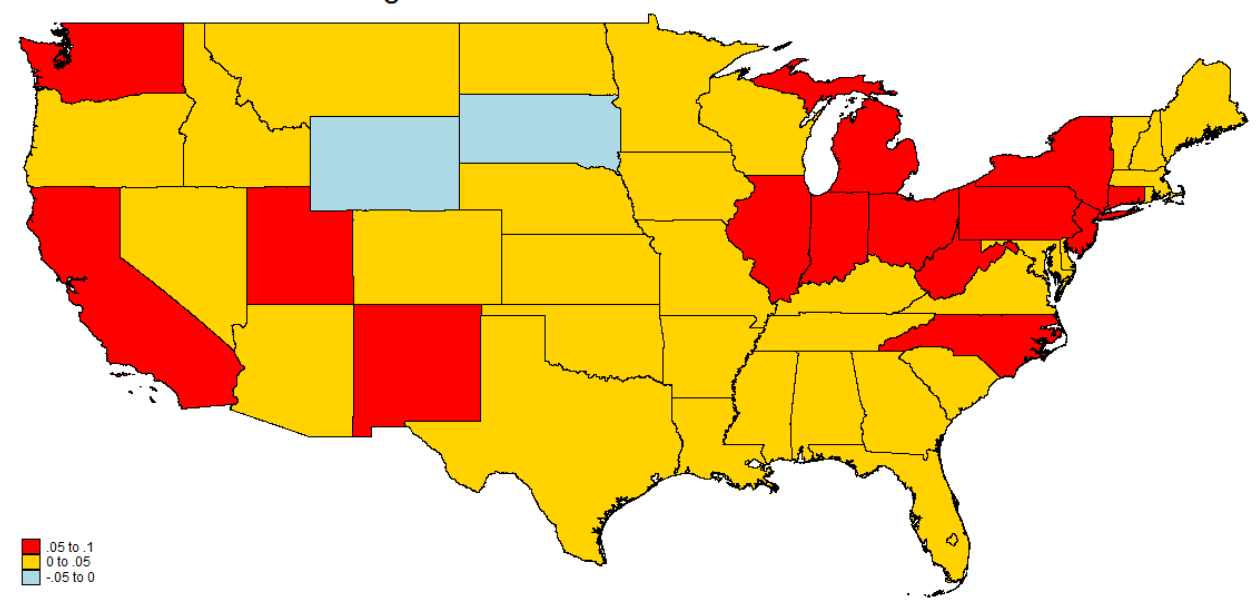

Change in AG 5 from 1976-1978 to 2010-2012

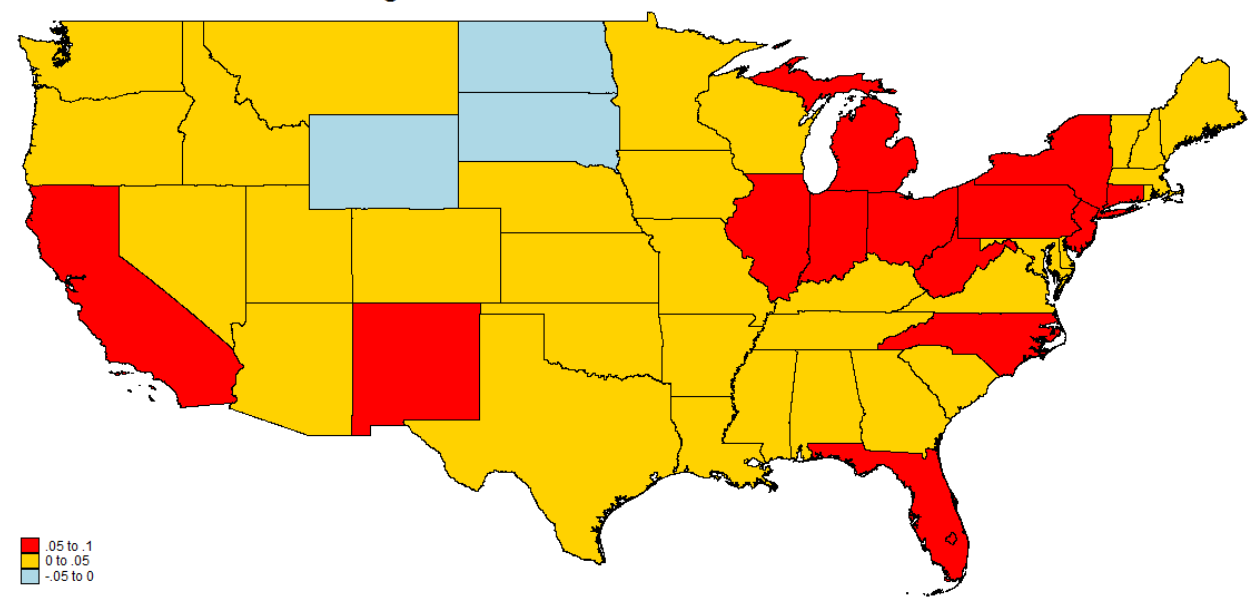

Figure 9: Changes in Gini (top), AG 3 ( $\{\mathrm{H}, \mathrm{EDU}, \mathrm{IND}\}$, middle), and AG 5 (\{H, EDU, IND, HH, STATE\}, bottom) from $1976-1978$ to $2010-2012$ 
from hours worked or educational outcomes would require different policies (if any) than income inequalities stemming from pure gender or race differentials (and therefore potentially discrimination).

We find that educational outcomes are able to explain a much larger portion of inequality today than 45 years ago. In fact, over 35 percent of the inequality explained by the variables in this study (the major variables included in conventional wage regressions) can be explained by educational outcomes today - as opposed to only 15 percent in the mid-1970s. However, none of the prominent wage determinants from the CPS dataset employed here can fully explain the general long-run trend in rising wage inequality. In this context, we confirm conclusions from Lemieux (2006b), in that education plays a larger role in determining inequality today, but reject education as the primary driver for the general upward trend in wage inequality. Overall, hours worked, educational attainment, marital status, number of children, and geographical location are unable to account for the majority of increased wage disparity since 1967. In fact, in aboslute and relative terms, the adjusted Gini coefficient (a measure of "unfair" inequality) has risen more than the raw Gini, regardless of what factors one wishes to consider being within an individual's set of responsibility. Thus, we cannot rule out alternative explanations for the rise in income inequality, such as the importance of top earners (e.g., see Piketty and Saez, 2003).

As a next step, we analyze developments in raw and adjusted inequality within gender and race. Especially here, breaking down inequality into its sources reveals interesting findings. For instance, the pure earnings disparity among black women has decreased since the late 1960s. However, once wage inequalities arising from hours worked and educational attainment are considered as fair, inequality among black women today is higher than 45 years ago. Another interesting finding in our study shows that income inequality among men has increased substantially more than income inequality among women. In fact, until 1990 wages among men were more evenly distributed than among women, but since then the data shows the opposite development.

Finally, we break down raw and adjusted wage inequality by U.S. states. Not surprisingly, the majority of the states experienced rising wage inequality over the past 35 years, yet some states actually experienced a decrease. This holds especially true for the northern states (e.g., 
Minnesota, North Dakota, or South Dakota), but also Oklahoma and Delaware. However, once we hold people accountable for a couple of major wage determinants - such as hours worked, educational outcomes, or job industry - the map of inequality developments changes. Eventually, only South Dakota and Wyoming consistently show a decrease in unfair wage inequality since 1976, no matter which set of variables we assume as part of one's responsibility.

Beyond these economic conclusions, showing the diversity of the types and sources of inequality within gender, race, and U.S. states, this paper highlights potential political lessons. In general, there exists an urgent need to understand the sources of rising inequality. In this context, using large individual level databases proves to be important, as it allows for a more detailed look at the sources of wage inequality. This paper shows that the reasons for the rise in inequality can differ across gender, race, or geographical location. Thus, raw Gini coefficients provide little direction in forming potential policy recommendations aimed at combating wage disparities, especially if policymakers wish to differentiate between equality of opportunity and equality of outcomes.

There are several limitations of our analysis that should be noted, some of which may provide fruitful avenues for future research. First, our sample only includes employed individuals, which means that changes in labor force participation are not directly captured. Second, data availability in our study does not allow us to measure the influence of the tax code and other governmental policies in mitigating income inequality. Third, a few prominent wage determinants are absent in the CPS data set, such as measurements for total work experience, field of study, or the quality of academic institutions attended. Nonetheless, we view this paper as a valuable exercise that begins to address the dichotomy of personal views on inequality and its sources, allowing for greater insight into long-term trends of income inequality.

\section{References}

Aaberge, R., Mogstad, M., and Peragine, V. (2011). Measuring long-term inequality of opportunity. Journal of Public Economics, 95(3):193-204.

Alesina, A. and Angeletos, G.-M. (2005). Fairness and redistribution. American Economic Review, 95(3):960-980. 
Almås, I., Cappelen, A. W., Lind, J. T., Sørensen, E. Ø., and Tungodden, B. (2011). Measuring unfair (in)equality. Journal of Public Economics, 95(7):488-499.

Almås, I., Havnes, T., and Mogstad, M. (2012). Adjusting for age effects in cross-sectional distributions. Stata Journal, 12(3):393-405.

Armour, P., Burkhauser, R. V., and Larrimore, J. (2013). Deconstructing income and income inequality measures: A crosswalk from market income to comprehensive income. American Economic Review, 103(3):173-177.

Bound, J. and Johnson, G. (1992). Changes in the structure of wages in the 1980's: An evaluation of alternative explanations. American Economic Review, 82(3):371-392.

Bourguignon, F., Ferreira, F. H., and Menendez, M. (2007). Inequality of opportunity in Brazil. Review of Income and Wealth, 53(4):585-618.

Burkhauser, R. V., Feng, S., and Jenkins, S. P. (2009). Using the P90/P10 index to measure US inequality trends with current population survey data: A view from inside the Census Bureau vaults. Review of Income and Wealth, 55(1):166-185.

Burkhauser, R. V., Feng, S., Jenkins, S. P., and Larrimore, J. (2011). Estimating trends in US income inequality using the Current Population Survey: The importance of controlling for censoring. Journal of Economic Inequality, 9(3):393-415.

Cappelen, A. W., Hole, A. D., Sørensen, E. Ø., and Tungodden, B. (2007). The pluralism of fairness ideals: An experimental approach. American Economic Review, 97(3):818-827.

Carpantier, J.-F. and Sapata, C. (2012). Unfair inequalities in France: A regional comparison. Working Paper.

David, H., Katz, L. F., and Kearney, M. S. (2006). The polarization of the US labor market. American Economic Review, 96(2):189-194.

Dynan, K. E. and Ravina, E. (2007). Increasing income inequality, external habits, and selfreported happiness. American Economic Review, 97(2):226-231. 
Figueiredo, E. (2011). A note on the measurement of unfair inequality in Brazil. Economics Bulletin, 31(4):2944-2951.

Figueiredo, E. and Junior, J. L. d. S. N. (2011). More equal but not so fair: An analysis of Brazilian income distribution from 1995 to 2009. Empirical Economics, 46(4):1-13.

Gaertner, W. and Schwettmann, L. (2007). Equity, responsibility and the cultural dimension. Economica, 74(296):627-649.

Grove, W. A., Hussey, A., and Jetter, M. (2011). The gender pay gap beyond human capital: Heterogeneity in noncognitive skills and in labor market tastes. Journal of Human Resources, $46(4): 827-874$.

Hopkins, E. and Kornienko, T. (2010). Which inequality? The inequality of endowments versus the inequality of rewards. American Economic Journal: Microeconomics, 2(3):106-37.

Katz, L. F. and Murphy, K. M. (1992). Changes in relative wages, 1963-1987: Supply and demand factors. Quarterly Journal of Economics, 107(1):35-78.

Larrimore, J., Burkhauser, R. V., Feng, S., and Zayatz, L. (2008). Consistent cell means for topcoded incomes in the public use march CPS (1976-2007). Journal of Economic and Social Measurement, 33(2):89-128.

Lefranc, A., Pistolesi, N., and Trannoy, A. (2009). Equality of opportunity and luck: Definitions and testable conditions, with an application to income in France. Journal of Public Economics, 93(11):1189-1207.

Lemieux, T. (2006a). Increasing residual wage inequality: Composition effects, noisy data, or rising demand for skill? American Economic Review, 96(3):461-498.

Lemieux, T. (2006b). Postsecondary education and increasing wage inequality. American Economic Review, 96(2):195-199.

Mankiw, N. G. (2013). Defending the one percent. Journal of Economic Perspectives, 27(3):2134. 
Pignataro, G. (2012). Equality of opportunity: Policy and measurement paradigms. Journal of Economic Surveys, 26(5):800-834.

Piketty, T. and Saez, E. (2003). Income inequality in the United States, 1913-1998. Quarterly Journal of Economics, 118(1):1-39.

Ramos, X. and Van de Gaer, D. (2012). Empirical approaches to inequality of opportunity: Principles, measures, and evidence. Technical report, Discussion Paper series, Forschungsinstitut zur Zukunft der Arbeit. 